\title{
Dendrimers: Amazing Platforms for Bioactive Molecule Delivery Systems
}

\author{
Claudia Sandoval-Yañez ${ }^{1, *}$ and Cristian Castro Rodriguez ${ }^{2}$ \\ 1 Institute of Applied Chemical Sciences, Faculty of Engineering, Universidad Autonoma de Chile, \\ El Llano Subercaseaux 2801, San Miguel 8910060, Santiago-Chile, Chile \\ 2 Departamento de Química, Facultad de Ciencias, Universidad de Tarapacá, Avenida General Velásquez 1775, \\ Arica-Chile 1000007, Chile; cicastror@uta.cl \\ * Correspondence: claudia.sandoval@uautonoma.cl; Tel.: +56-2-23036678
}

Received: 17 December 2019; Accepted: 15 January 2020; Published: 24 January 2020

check for updates

\begin{abstract}
Today, dendrimers are the main nanoparticle applied to drug delivery systems. The physicochemical characteristics of dendrimers and their versatility structural modification make them attractive to applied as a platform to bioactive molecules transport. Nanoformulations based on dendrimers enhance low solubility drugs, arrival to the target tissue, drugs bioavailability, and controlled release. This review describes the latter approaches on the transport of bioactive molecules based on dendrimers. The review focus is on the last therapeutic strategies addressed by dendrimers conjugated with bioactive molecules. A brief review of the latest studies in therapies against cancer and cardiovascular diseases, as well as future projections in the area, are addressed.
\end{abstract}

Keywords: dendrimers; bioactive molecules; drug delivery systems; cancer disease; cardiovascular disease

\section{Introduction}

Today, most pathologies, whether chronic or not, are treated through oral, mucosal, dermal, and transdermal administration of drugs. Most of the effects of the drugs used to cure diseases have a high percentage of inhibition of the target agents that generate the pathology or significantly reduce the symptoms of it. The problem with some drugs is that they must be administered in high doses, to reach a positive therapeutic, but the higher doses usually result in unwanted side effects [1-4]. These side effects are because some drugs that have low bioavailability, so they must be administered in high doses. For this reason, in the last decades, the challenge has been focused on the investigation of the targeted drug delivery systems [5-13]. There is a large variety of organic systems that have been considered as drug delivery systems, such as micelles, liposomes, and polymeric nanoparticles. All these systems must meet some requirements to be applied as the drug carrier agents, namely nanoscale size, biocompatible, bioresorbable, water solubility, and monodisperse structure [13-16]. Among these synthetic nanostructures, dendrimers have been one of the most studied in the last twenty years.

Dendrimers are very attractive macromolecules, both from the challenge proposed by their design and chemical synthesis and from the range of applications they have given in different areas. They are three-dimensional structures highly branched and radially symmetrical (Scheme 1). They have three very well defined structural regions, a central junction structure (core) with multiple internal repeating units covalently linked to the nucleus (called generations, G), and finally, a terminal chemical structure that forms the multifunctional surface of a dendrimer [17]. These attractive macromolecular architectures were reported in the late 70's by Vögtle et al. and have been the subject of numerous studies since then. In later years Tomalia, Newkome, and Frechet, independently, reported two new synthetic 
routes to obtain dendrimersoma [18,19]. The chemical architecture of the dendrimers overcome other polymers (linear, branched or cross-linked) since they have attributes like monodisperse structures (desirable for applications in nanomedicine), control over macromolecular growth, multifunctional surface structure, internal cavities available to host small molecules, increased solubilization, among many other advantages that enable them to be used in several fields. Nanomedicine is one of the applications in which dendrimers have been studied and tested, using as a nanocarrier bioactive molecules, imaging agents, or transfection of genes.

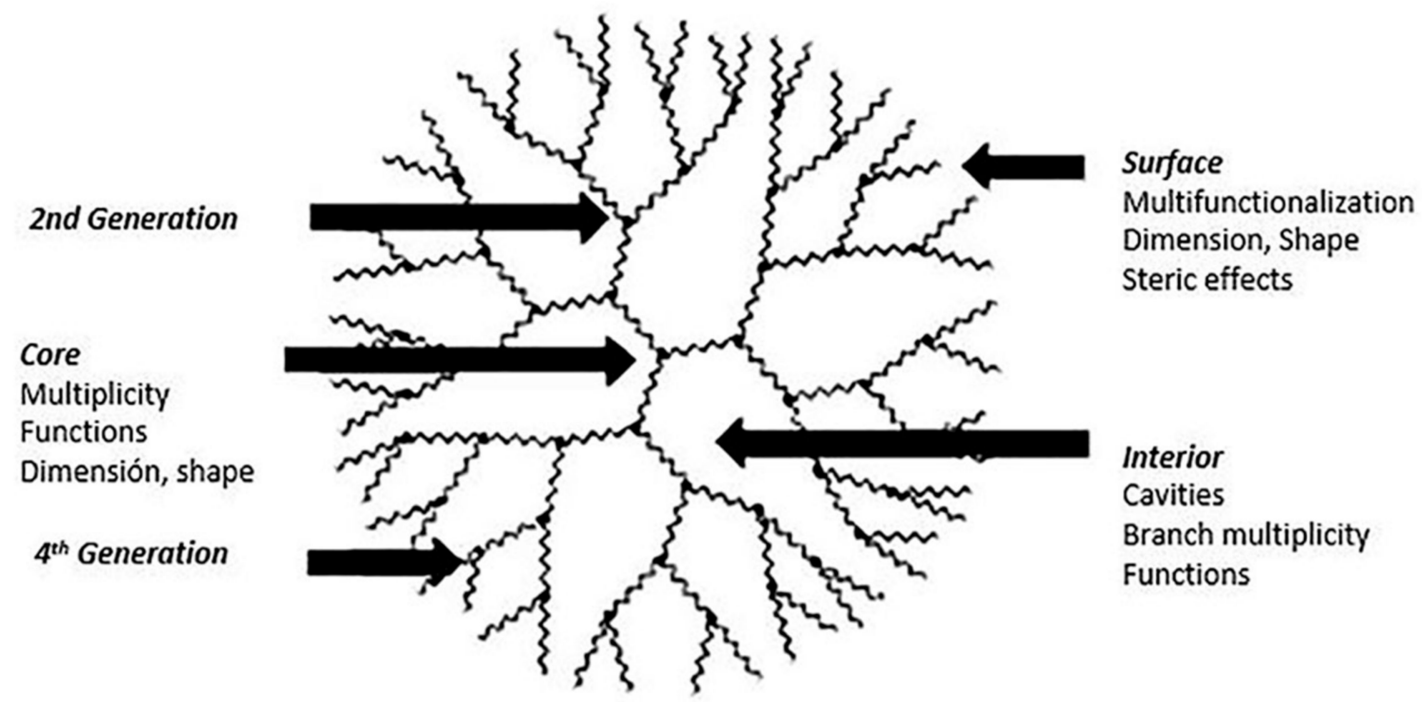

Scheme 1. Schematic representation of a dendrimer of fourth-generation. This scheme was provided thanks to Reference [20].

In the last ten years, numerous publications, over 29 thousand articles, and more than 6 thousand reviews (source: WOS, January 09-2020) have been published on a drug delivery system based on dendrimers. The present review primarily focuses on progress carried out in the last few years in dendrimers and their applications as drug delivery systems. Here, we will give an overview of the dendrimer types and their properties, and in a second part give we will present pharmacodynamic and pharmacokinetic studies which have been done regarding the transport and control release of bioactive molecules based on dendrimers. Finally, the latest studies concerning the release of drugs based on dendrimers focused on cancer and cardiovascular diseases and prospects are reported.

\section{Dendrimers Types and Their Properties}

Dendrimers are three-dimensional macromolecules that have a radial architecture, which contain several branching points, and its dimensions are in the nanoscale range (Scheme 1). The chemical nature of the dendrimers can be of organic or inorganic origin with a central nucleus constitutes its morphology and, together with it, grow the so-called "generations" (G) or branches. Branches that grow and give size to the dendrimer, finally they are the groups of the periphery or terminal groups, those that have the virtue of being tunable, according to the application given to the dendrimer. The synthesis of the different types of dendrimers contemplate two mostly strategies: convergent and divergent methods. The synthesis of dendrimers through divergent method initially proposed by Vögtle [21], and subsequently developed independently by Tomalia [18] and Newkome [22,23], begins with a polyfunctional molecule that acts as a core, on which successive layers of monomer units are chemically bonded (Scheme 2a). The repetitive sequence of two reactions is used to add generations to the core, which correspond to the activation of the functional groups and their subsequent assembly with the other monomers. The advantage of the divergent method is that high molecular weight architectures can be achieved on a nanometric scale. The main disadvantage is that terminal functional groups cannot 
always be reacted stoichiometrically, leading to structural defects. The convergent method introduced by Hawker and Fréchet [24] involves the obtaining dendritic fragments called dendrons, through repetitive reactions, which are joined at a later stage to a central core consisting of a polyfunctional molecule (Scheme $2 b$ ). The functionality of the core determines the number of dendrons that can be bound. Convergent synthesis is normally used only to form dendritic structures of low generations, since steric hindrance limits the coupling of bulky dendrons to a core of reduced dimensions.

Recently, two new dendrimer synthesis strategies have been reported, "Lego" and "Click" chemistry [25]. The type of dendrimer required determines the type of synthesis strategy that is applied.

Conventional approaches

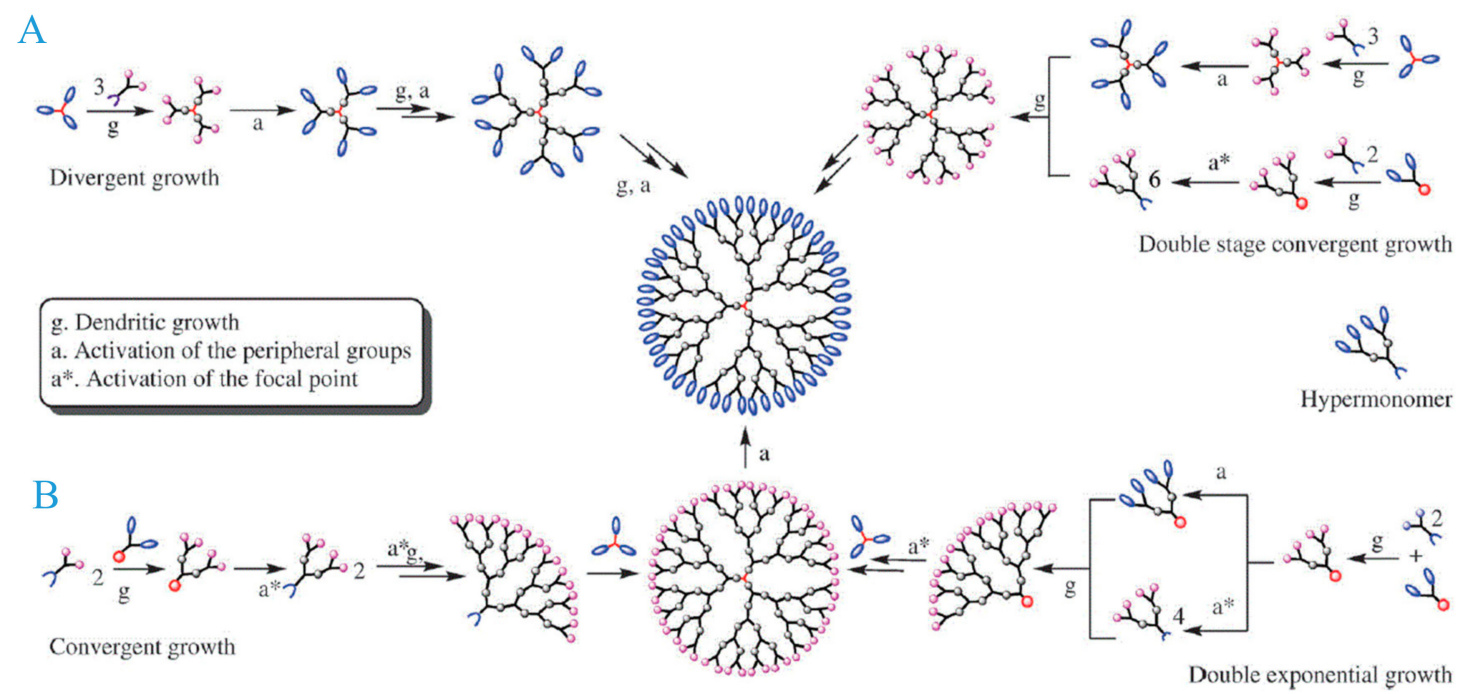

Scheme 2. Simplified representation of dendrimers synthesis by (A) divergent and (B) convergent strategies. This scheme was provided thanks to Reference [26].

\subsection{Orthogonal Coupling or "Lego" Chemistry Strategy}

Dendrimers of different chemical natures can be synthetized by this strategy, namely dendrimers containing polycarbamate/urea, phosphorus, aromatic polyamide, among others, to obtain an increase of the number of end groups, and this form high generation dendrimers [27,28]. Majoral et al. synthetized high generation dendrimers with 750 different end groups obtained in three steps [20,29]. This methodology to obtain dendrimers is advantageous since it used a minimum amount of solvent, products of facile purification, and only nitrogen and water are obtained as by-products.

\section{2. "Click" Chemistry Strategy}

The "click" chemistry methodology allows obtaining new compounds of biological interest from highly energetic reagents through a series of highly thermodynamic and orthogonal processes. These two characteristics, high reactivity and orthogonality, allow the click-type reactions to proceed with quantitative yields and, therefore, only simple purifications are required. "Click" chemistry is a synthetic methodology remarkable which its care with the environment since it only generates as a by-product sodium chloride, mainly [30]. This reaction mechanism has been used both syntheses and modification of polymer and materials [31]. Divers types of polymers can be obtained by this strategy, specifically through called "thiol-ene" chemistry reactions. In recent years, "thiol-ene" chemistry has been used to synthesized dendrimers, star polymers and hyperbranched polymers. A comprehensive review by Lowe [31], describes the reaction mechanisms of "thiol-yne" click coupling chemistry, and their applications in dendrimers synthesis using different combinations of AB2 and CD2 monomers (see Scheme 3). In the same way, Amir et al. [32] carried out a "click" strategy to obtain 
fourth-generation dendritic scaffold with two dyes attach internally with coumarin units through a cleavable linker and on superficial region with Alexa647 dye. In addition, some protonated amino groups remained on the surface of the dendritic system, which allows the internalization of the system within the cells. This strategy allowed the monitoring of the dendritic scaffold within the cellular environment, and the appearance of fluorescence could also be observed, due to the release of coumarin dye to the hydrolytic enzyme cleavage inside the cell (Figure 1). This type of thiol-yne and thiol-epoxy synthesis reaction strategy allows versatility to obtain dendritic platforms for transport and release of drugs to target tissues.
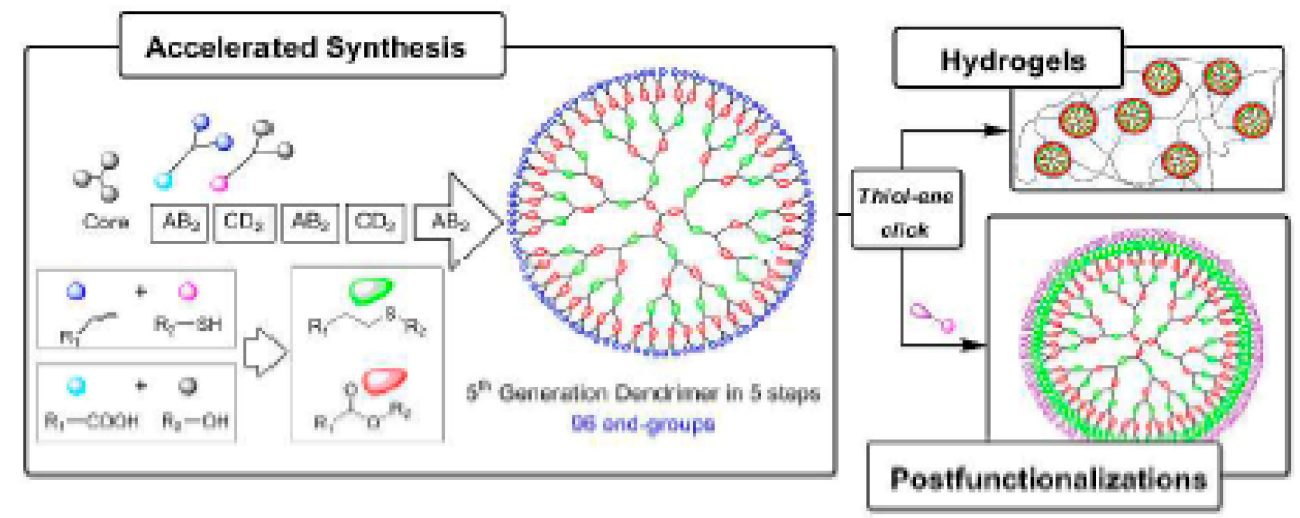<smiles>O=C(OCCS)C(CO)(CO)CO</smiles>

Thiol functional $A B_{2}$ dendrons<smiles>C=CCOCC(C)(COCC=CC)C(=O)O</smiles><smiles>C=CCOCC(CC)(COCC=CC)COC(=O)CCC(C)=O</smiles>

\section{Alkene functional $A B_{2}$ and $C D_{2}$ dendrons}

Scheme 3. General illustration for the synthesis of dendrimers using "Click" chemistry method by of a combination of "thiol-ene" and esterification reactions. This scheme was provided thanks to Reference [33].

Dendrimers have attractive properties since it offers great advisability for the storage, transport, and controlled release of bioactive molecules. A triazole-base dendrimer contained bile acid surface groups was synthesized by "click" chemistry strategy [34]. In addition, "Janus" dendrimers and "onion peel" were obtained using this strategy [35]. Pérez-Campos et al. has synthesized two different dendrimeric structures and the precursor dendron with aimed to evaluate their role in the antichagasic activity as drug carriers and as prodrugs. The dendrons were derived from ethynylestradiol molecules modified with PAMAM type fragments through a "click" reaction to produce a triazolic ring [36]. 


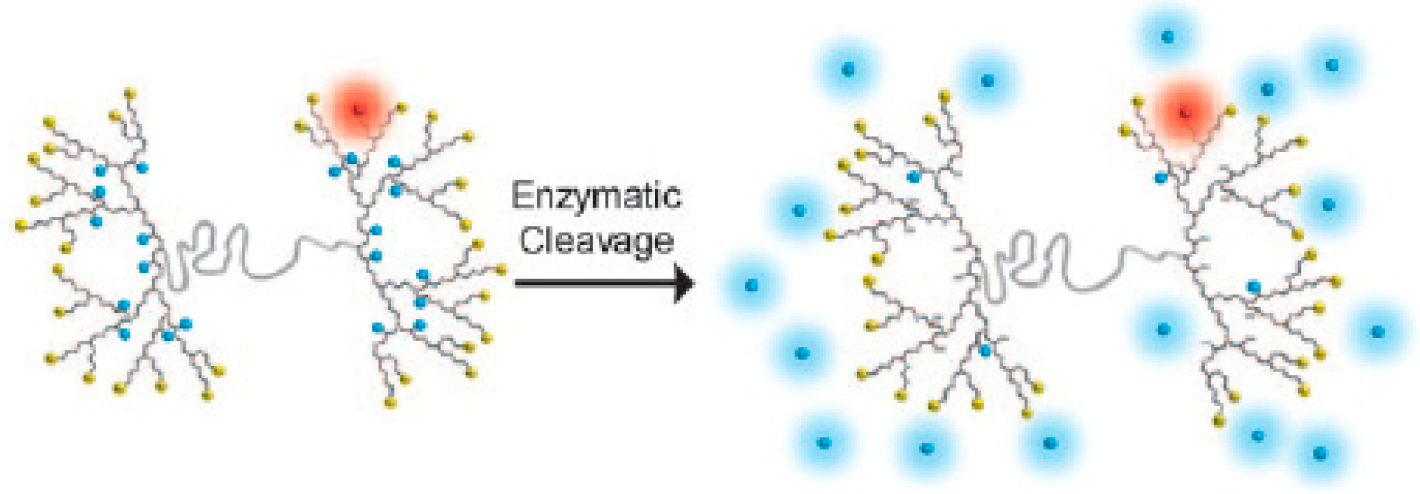

Figure 1. Scheme of the design of a dendritic platform, containing a dual functionalization and surface protonated amino groups (yellow). In blue: the dye internally bound to the dendritic system, through a cleavable junction by hydrolytic enzymes. In red: the cell tracking dye not cleavable by hydrolytic enzymes. This scheme was provided thanks to reference [32].

Table 1 gives a list of different types of dendrimers obtained with the synthetic strategies described above and the authors who have reported these works. Moreover, the reader can go to a review completely dedicated to the different methods of dendrimer synthesis, recently published by Lyu et al. [37]

Table 1. Summary of some synthetic strategies and dendrimers synthesized.

\begin{tabular}{|c|c|c|}
\hline $\begin{array}{l}\text { Synthesis } \\
\text { Strategy }\end{array}$ & Dendrimer Type & Authors \\
\hline \multirow{8}{*}{ Divergent } & Sulfonimide-based dendrimers & Lukin et al. [38] \\
\hline & Tetraphenylmethane-ethynylene dendrimer & Julio I. Urzúa et al. [39] \\
\hline & Rhodamine B dendrimers & Lyu et al. [37] \\
\hline & Porphyrin and metalloporphyrin dendrimers & Alsehli et al. [40] \\
\hline & Poly(amidoamine)(PAMAM) dendrimer-grafted graphene oxide & Gholipour-Mahmoudalilou et al. [41] \\
\hline & Benzylic viologen dendrimers & Kathiresan et al. [42] \\
\hline & Newkome-type polyamide-based dendrimers & Kaufman et al. [43] \\
\hline & Phosphorus containing dendrimer & Dadapeer et al. [44] \\
\hline \multirow{7}{*}{ Convergent } & G2-PEG dendrimer & Patil et al. [45] \\
\hline & dodecaruthenium organometallic dendrimer & Merhi et al. [46] \\
\hline & Azobenzene core dendrimer with Chalcone motif & Selvarani et al. [47] \\
\hline & poly(amino-ester) dendrons & Dayyani et al. [48] \\
\hline & 2,2-bis-(hydroxymethyl)-propionic acid (bis-MPA) & Guizzardi et al. [49] \\
\hline & $\begin{array}{l}\text { hyperbranched linear dendrimers } \\
\text { mesitylene-based polyamine dendrimer }\end{array}$ & Singh et al. [50] \\
\hline & $\begin{array}{c}\text { poly } \epsilon \text {-caprolactone linear block, poly(amino-ester) dendritic } \\
\text { block and m-PEG linear block }\end{array}$ & Khoee et al. [51] \\
\hline \multirow{3}{*}{ Click chemistry } & Glycopeptide dendrimers based on $\beta$-cyclodextrin & Pu-Guang et al. [52] \\
\hline & poly(thioglycerol-2-propionate) dendrimers & Fan et al. [53] \\
\hline & carbazole core diblock codendrimers & Han et al. [54] \\
\hline
\end{tabular}

\section{Dendrimers Properties}

\subsection{Monodispersity}

Dendrimers are monodispersed macromolecular architectures, unlike to linear polymers, this is an important property to be applied in nanomedicine. High-performance liquid chromatography (HPLC), size exclusion chromatography (SEC), mass spectrometry (MS), gel electrophoresis, and transmission electron microscopy (TEM) techniques have been extensively using to verify the monodispersity of dendrimers $[55,56]$. The advances in new synthetic strategies have allowed obtaining better yields in monodisperse dendrimers [57]. Recently, Malkoch et al. [58] presented a simple post-functionalization approach of monodisperse dendrimers of bis-MPA from generation one to five. Two types of 
esterification reactions were used to carry out the synthesis: (a) activation of BOC-protected $\beta$-alanine through anhydride coupling, (b) fluoride-promoted esterification with activation by carbonyl diimidazole. This last reaction had a substantial improvement in product purity, and scalability.

\subsection{Nano-Size}

Regarding the size of dendrimers, these have a nanoscale dimension, and can be considered similar to other biomacromolecules such as proteins, which makes them very attractive from that point of view $[59,60]$. The size of a dendrimer is determined by the number of generation. Therefore, it is easy to think that if the number of generations increases, the size of the dendrimer will also do so [60-62]. Polyamidoamide (PAMAM) an important class of commercial dendrimers, where the diameter of the generations 1-10 increases from 1.1 to $12.4 \mathrm{~nm}[27,63]$. A recent study carried out by Biswas et al. [64] on the effect of $\mathrm{pH}$ on the size and conformational structure of Poly(propylene imine) dendrimers through molecular dynamics simulation, shows that the size of dendrimers increase according to decreasing of $\mathrm{pH}$ for all generations (G3 to G8) (Scheme 4). This behavior may be due to the electrostatic repulsions between the protonated primary and tertiary amine groups at neutral and low $\mathrm{pH}$, the degree of back-folding decrease with the decreasing in the $\mathrm{pH}[65,66]$. These types of studies are important since they can be used to monitor and interpret the conformational behavior of dendrimers as a function of $\mathrm{pH}$, for several applications such as drug delivery systems. In addition, Diaz et al. [67] has determine that there is a direct relationship between the size of the dendrimer and its circulation time in the bloodstream. The functionalization of the end-groups in the outer surface of dendrimers with different functional groups modify their physicochemical properties and biological behaviors [68,69]. Recently, dendrimers decorated with positively charged amino acids on the superficial were synthesized [70]. Recently, Govender et al. [71] formulated and evaluated novel $\mathrm{pH}$-responsive lipid-dendrimer hybrid nanoparticles for the targeted delivery of vancomycin in the site infection. The study has shown that the $\mathrm{pH}$-responsive release of nanoparticle enhanced antibacterial efficacy and intracellular delivery as antibiotic.

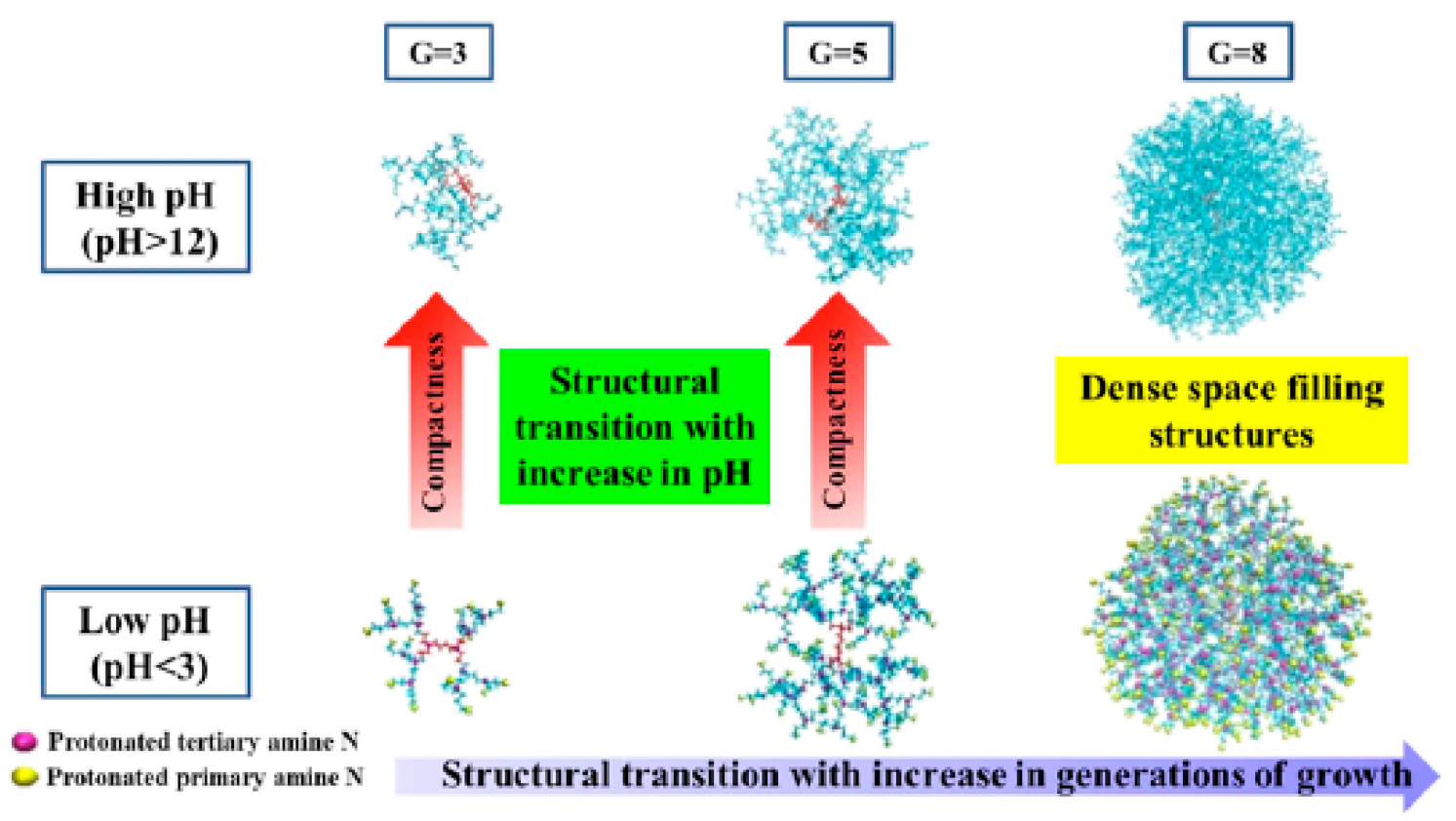

Scheme 4. Illustration of the variation of the dendrimer's conformation with respect to $\mathrm{pH}$ value and their generation. This scheme was provided thanks to Reference [64]. 


\subsection{Physicochemical Properties}

In recent years, numerous studies about the physicochemical properties of dendrimers have been carried out since these have several outstanding physicochemical properties, which make them synthetic macromolecules with a wide range of applications [17,72,73]. Dendrimers have multifunctional surfaces that give the possibility of modifying their solubility and interactions with other molecules in different environments. An adequate solubility has been one of the problems when selecting some bioactive molecules for pharmaceutical product development. Drugs with low solubility in the bloodstream determine the pharmaceutical and therapeutic performance, so dendrimers are an excellent alternative to enhance a low solubility drug [74,75]. Many compounds that are excellent candidates as potent drugs against some pathologies do not continue with more advanced studies, due to their limited aqueous solubility. In recent years, several researches have been focused to solubilize powerful hydrophobic drugs to increase their bioavailability [76]. Some research has been conducted on the study of physicochemical parameters such as, water solubility, $\log P$, polar surface area, and the number of hydrogen bond acceptor and hydrogen bond donors as a measurement to elucidate the drug molecules solubility grade [77]. The modification of the surface of dendrimers offers a great opportunity to improve not only the solubility of drug-like molecules but also to enhance the biocompatibility and permeability in a cellular environment, i.e., improve their physicochemical properties. The polycationic periphery of the dendrimer promotes interactions with lipids of the cell membrane, enhancing drug solubility. The nanoformulations, such as prodrugs based on dendrimers modification have been intensively studied to improve the bioavailability and solubility of drugs [78]. Highly hydrophobic drugs incorporated into polycationic dendrimers through physical through electrostatic interactions and hydrogen bonding can be obtained. Pentacyclic triterpenoid acids encapsulated into the G4, and G5 amino acids-modified PAMAM dendrimers have been prepared and solubilized, allowing a better bioavailability, and an increased pharmacokinetic [79]. The different interactions present between dendrimers and drugs, namely electrostatic interactions, dispersion forces, hydrophobic interactions, or hydrogen bonds among others, can ensure the formation of complexes. The types of interactions are important, not only because they determine the stability of the dendrimer-drug complexes, but they are also crucial to establish the kind of mechanism of uptake of the nanoformulations into the cell's interior [73]. A cytotoxicity grade can occur depending on the type of interactions between the dendrimer and the different lipidic membranes.

\subsection{Dendrimer Interactions with Membranes}

As previously it has mentioned, the different kinds of interactions present between dendritic systems and membranes determine the success of the nanovehicles based on dendrimers [73]. The structural and organizational of biological membranes can vary depending on composition and charged lipids. Membrane lipids mainly phospholipids self-assemble form bilayers, where the hydrophobic interactions are main forces that support the membrane structures, which determine the thermodynamics of the system [80]. In addition, the membranes are also made up of integral or intrinsic proteins and peripheral proteins. The latter play an important role in various mechanisms, such as providing binding site for enzymes or signaling molecules. On the other hand, several sensitive techniques have been used to study the interactions between dendrimers and binding sites on the membranes, namely Z-potential, X-ray and neutron reflectivity, atomic force microscopy, ellipsometry, differential scanning calorimetry, and Raman spectroscopy, mainly. Recent studies about interactions of G2- and G4-PAMAM dendrimers and dipalmitoylphosphatidylcholine (DPPC) lipids evidenced that charged PAMAM dendrimers produce a perturbation due to penetration inside the DPPC vesicles alkyl chains by Raman scattering data [81]. The results show that the zeta potential of the vesicles increases linearly with the increase in the concentration of the positively charged dendrimer (Figure 2A). On the other hand, the hydrodynamic radius of DPPC liposomes at low dendrimer concentrations indicates the presence of pores with radius sizes comparable to those of membrane, (Figure 2B). Studies show that the dendrimer interacts with the DPPC liposome, both on the surface and in the hydrophobic 
region of the lipid bilayer. Such studies are crucial to propose dendrimers as attractive candidates for drug delivery systems. Those who must be to achieve biological targets such as tumor cells, since a solid tumor has a dense extracellular matrix, which restricts drug distribution within the tumor.
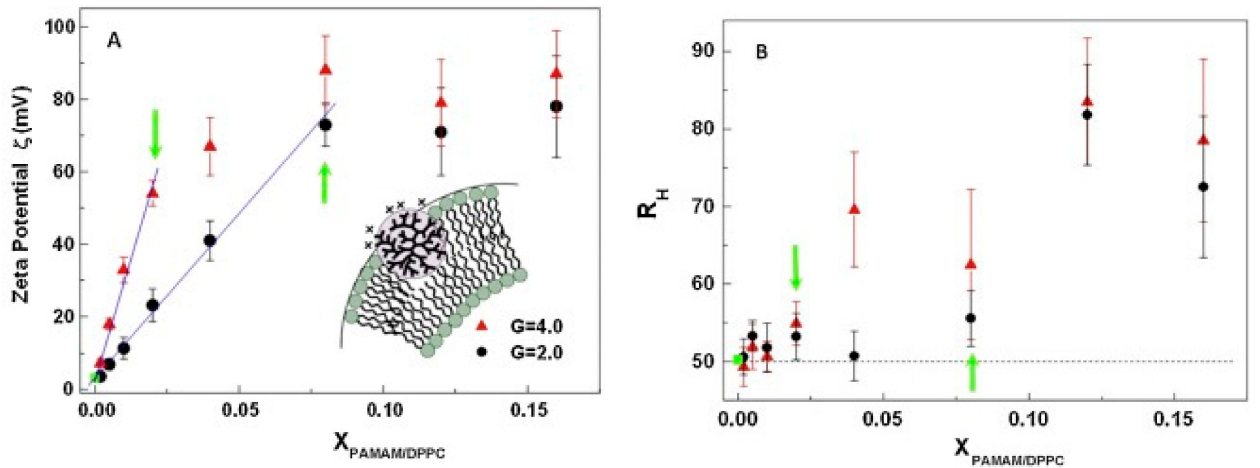

Figure 2. Measurements of: (A) Zeta potentials of extruded liposomes as a function of dendrimer-liposomes concentration, for G2-Poly(amidoamine) (PAMAM) and G4-PAMAM dendrimers. (B) Hydrodynamic radius of PAMAM-liposomes mixed system. This Figure was provided thanks to Reference [81].

In recent years, new strategies using nanoparticles to remedying the drug-resistant tumor cells, have been investigated [82-84]. The design of dendritic structures based on peptides functionalized with arginine have been used to cause a perturbing tumor membrane systems [85]. Arginine has been used to decorate the surface of dendrimers, since it can interact with the membrane lipids, through electrostatic interaction and hydrogen bonds. Furthermore, G4-PAMAM dendrimers functionalized with folate groups (FO) and polyethylene glycol (PEG) on the surface compare with G4-PAMAM without functionalizing were studied in hippocampal neurons [86] (Scheme 5). High cytotoxicity level was observed to G4-PAMAM in the cell viability assay. A reduction of toxic effect was observed to FO, while for PEG a better biocompatibility performance was shown. In addition, membrane permeability effects were carried to the same dendronized compounds, where G4-PAMAM showed an increased membrane permeability and loss of membrane integrity. Also, significant alterations caused by PFO and PEG in the capacitive currents during the test were not observed, indicating that the functionalization of G4 dendrimer is adequate to prevent effects on the membrane permeability [86].

a)

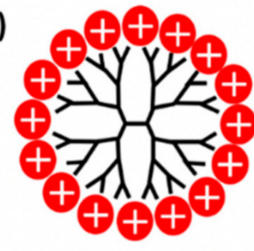

b)

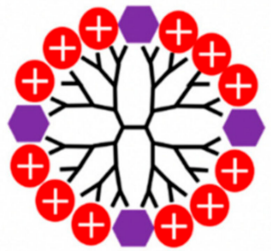

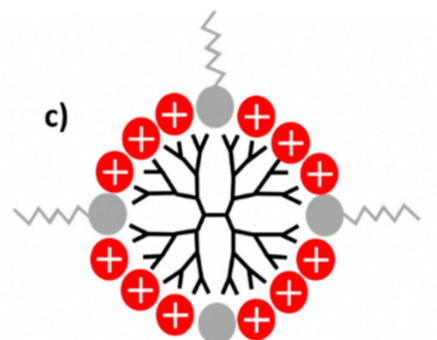

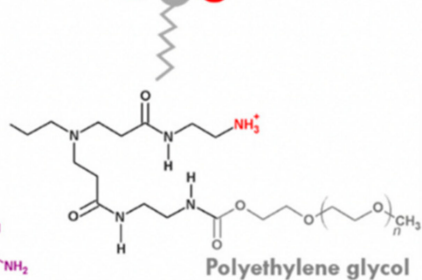

Scheme 5. Schematic representation of G4-PAMAM functionalized with polyethylene glycol (PEG), and folate terminal groups: (a) G4-PAMAM dendrimer with positively charged superficial groups; (b) G4-PAMAM dendrimer functionalized 25\% folate end-groups, and (c) G4-PAMAM dendrimer functionalized $25 \%$ PEG on the surface. This scheme was provided thanks to Reference [86]. 


\section{Dendrimers to Drug Delivery Systems Applications}

As mentioned earlier, thousands of reviews and articles have been published in the last decade on transport and contracted release of drugs by nanoparticles. These delivery systems have been of a relevant interest from industry to academic researches. The challenges in drug delivery systems are focused on solving the inefficient distribution of the drugs to the target tissues and the side effects improvement after drug administration that can influence both pharmacokinetic profiles as the biodistribution of them. The dendrimers, as we have said before, constitute a class of nanoparticles with physicochemical characteristics that make them very attractive in nanomedicine applications, more specifically as drug delivery systems (DDS). As previously mentioned, these extraordinary dendritic macromolecules have an improved membrane permeability and tumor retention effects [87-89], due to their suitable structural properties and size control.

Dendrimers as DDS can improve key points in transport and biodistribution such as prolongation of the drug circulation time, enhance drug solubility, enhance tumor permeation and retention, protection of the drug from surroundings, and the ability to target diseased tissue, among others. As a strategy to minimize the cytotoxicity of PAMAM dendrimers, the positive surface charge of its surface has been modified with carboxymethyl chitosan (CMCS) [90-92]. Considering that, CMCS is an amphoteric polymer, sensitive $\mathrm{pH}$, and taking doxorubicin as a model drug for cancer, it is that the formulation of a nanoparticle between PAMAM dendrimer and CMCS based on electrostatic conjugation, can transport the drug and release it into the target tissue (Figure 3A). It is known that there is a slight difference between physiological $\mathrm{pH}$ (7.4) and extracellular $\mathrm{pH}$ of tumor cells (6.5), (Figure 3B) so PAMAM dendrimers decorated with CMCS showed promising in vitro results of doxorubicin release at $\mathrm{pH} 6.5$.

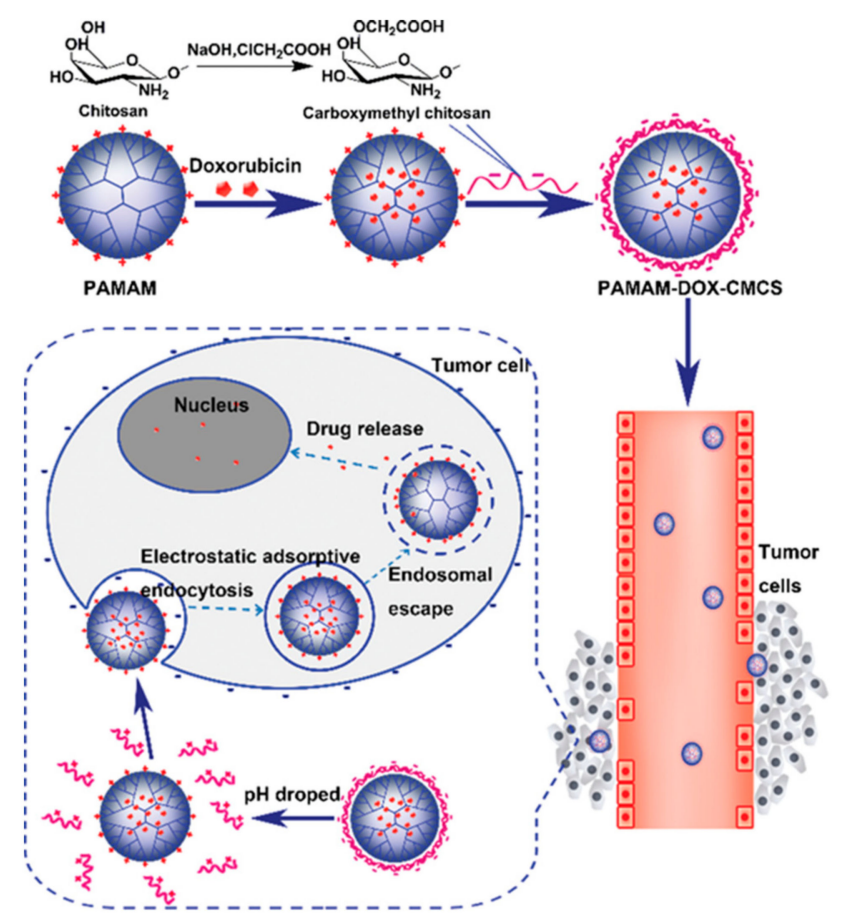

(A)

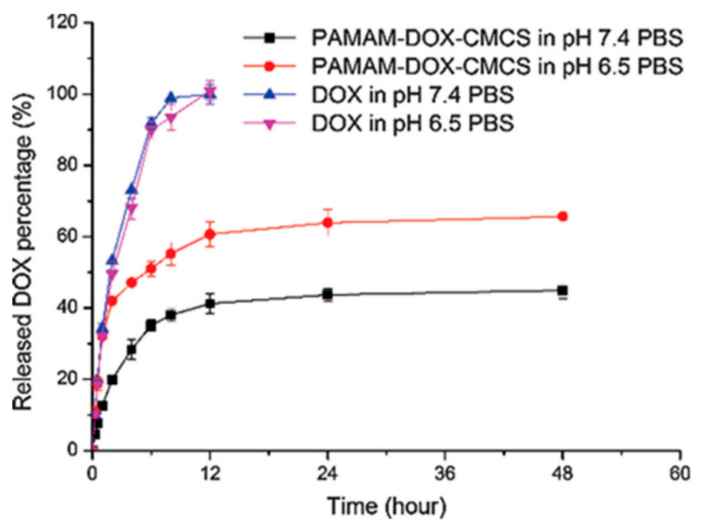

(B)

Figure 3. (A) Schematic representation of electrostatic conjugation of PAMAM dendrimers with carboxymethyl chitosan (CMCS) and the PAMAM-Doxorubicin-CMCS complex circulation through bloodstream and tumor microenvironment. (B) In vitro doxorubicin release with and without PAMAM-CMCS complex at pH 7.4 and pH 6.5. This Figure was provided thanks to Reference [90].

Thus, dendrimer-drug conjugates used as pharmacological strategies can be decorated depending on the target tissue, the pathology of interest, and the type of drug to be transported. Otto et al. 
studied the solubility and dissolution properties of furosemide/PAMAM dendrimers complexes with different generations containing amino and ester terminal groups [91]. Pharmacokinetic assessments in vivo show that the dendrimer complexes improved the bioavailability of the drug compared to the free drug. Other drug reported with low solubility, rifampicin (RIF) an antibiotic to the tuberculosis treatment [93], and important side effects since it suffers a hydrolysis reaction under gastric conditions was studied. Results of stability and drug-load capacity of the RIF-PAMAM complexes under different $\mathrm{pH}$ conditions were carried out by theoretical and experimental methods [94]. Studies demonstrated that twenty molecules of RIF per G4-PAMAM were determined according the results reported by molecular dynamic simulation tools. A theoretical study was carried out at two $\mathrm{pH}$ conditions, neutral and acid. At low pH, RIF molecules were quickly released to the solvent bulk, otherwise at neutral $\mathrm{pH}$ the RIF-PAMAM complex was more stable (Figure 4). Taking into account that drugs release strongly depends on the $\mathrm{pH}$, may impose restrictions to administration way, namely in the case of oral administration due to the low $\mathrm{pH}$ of the stomach. Nevertheless, preliminaries studies have shown that PAMAM dendrimers have the potential for pulmonary inhalation, which may be advantageous in the case of respiratory diseases treatment [95,96]. These studies allow us determine what kind of dendrimer it is necessary to synthetize, according to the type of the target tissue and the type of drug will be transported.

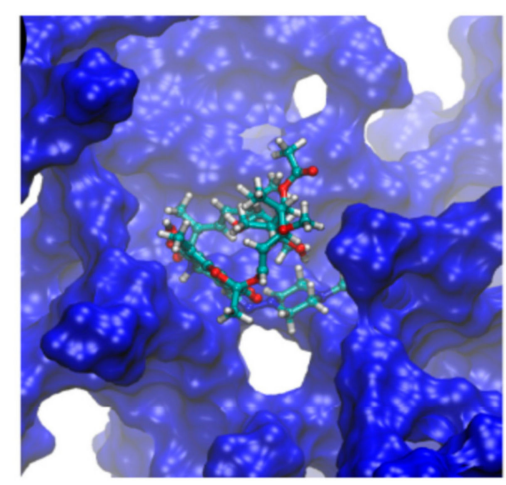

(A)

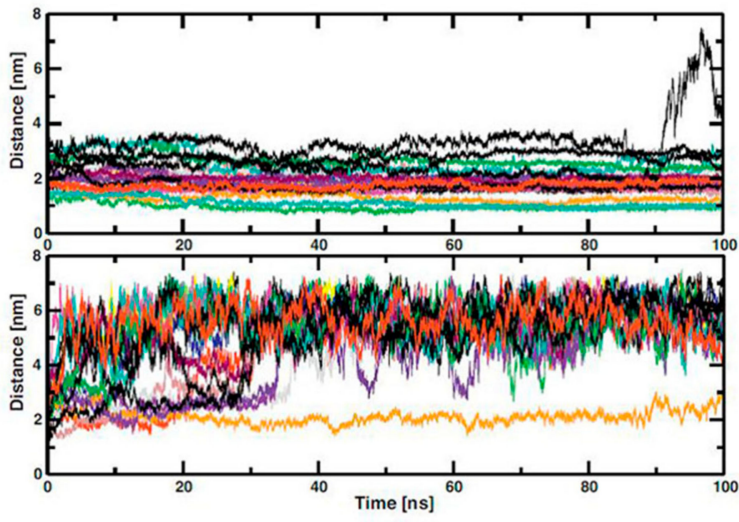

(B)

(C)

Figure 4. (A) a rifampicin (RIF) molecule inside one cavity of PAMAM dendrimer from molecular dynamic trajectory. $(\mathbf{B}, \mathbf{C})$ charts time of simulations against distance between center of mass of RIF molecules and dendrimer center of mass. (B) at neutral $\mathrm{pH}$ and $(\mathbf{C})$ at low $\mathrm{pH}$. This Figure was provided thanks to Reference [94].

\subsection{Dendrimer as Drug Delivery Systems to Cancer Treatments}

The different kinds of cancer that afflict the population are the leading cause of death worldwide. Despite the significant advances in medicine, there are still many challenges to be achieved in the treatment of cancer, to name a few, namely to decrease the side effects of some drugs [97,98], drug solubility improvement [76], drug-resistant cancer cell [84], and achieve a transport and targeted release of the drug [35]. Some of these advances focus on the use of dendritic nanoparticles as vehicles for the targeted transport of drugs against various types of cancer [85].

Studies about hepatic cancer have determined that asialoglycoprotein receptor (ASGPR) is specifically overexpressed on tumor cells, and shown high binding affinity with glycoproteins [99,100]. The above can be considered as an advantage because key parts of the glycoproteins can be obtained and grafted on the surface of nanoparticles (NP) to promote high-efficiency binding to hepatic tumor cells. N-acetylgalactosamine (NAcGal) ligands on a NP surface achieves selective intake into hepatic cancer cells [101-103]. Moreover, Kurivilla et al. synthesized G5-dendrimers containing NAcGal ligands tri-valent (NAcGal3) attached to the surface through a PEG linker and measured their ability to achieve hepatic cancer cells in comparison to mono-valent ligands [104] (Scheme 6). 


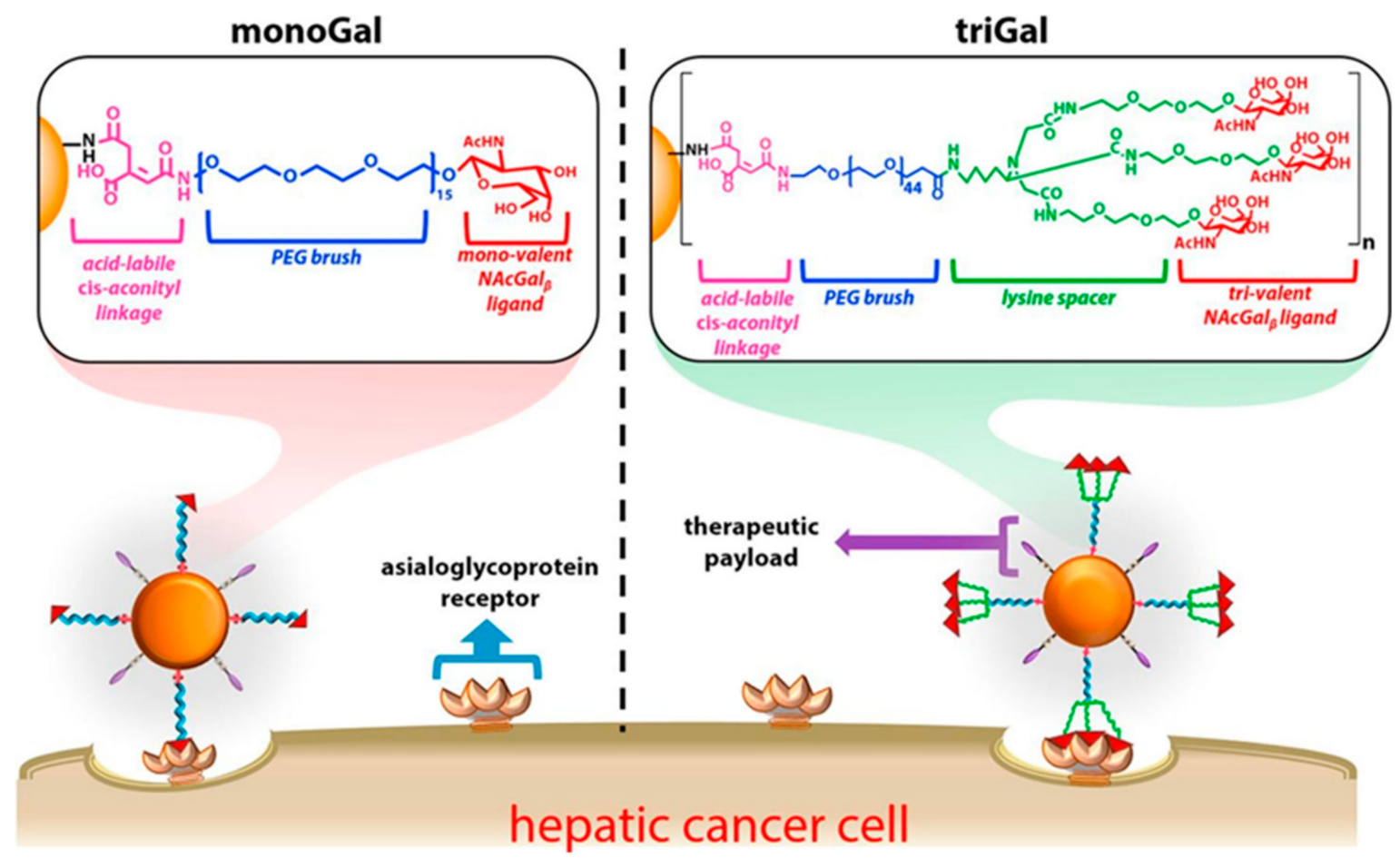

Scheme 6. Schematic representation of G5-PAMAM dendrimer functionalized with polyethylene glycol (PEG brush) connecting to both nono-valent and tri-valent N-acetylgalactosamine (NAcGal), and folate as a linkage. This scheme was provided thanks to Reference [104].

Metallodendrimers based on ruthenium to incorporate metals into dendritic scaffolds has been synthetize (Scheme 7) and characterize [105]. Several complexes based on ruthenium are in clinical phases against cancer therapies, however some complexes have had cytotoxicity problems. Evaluations of IC50 for metallodendrimers, organometallic complexes of ruthenium (Rucp) and cisplatin (cisPt) (a anticancer drug approval by FDA) in several of the carcinogenic cell lines were performed. The IC50 values for the metallodendrimers were the lowest compared to Rucp and cisPt. These results demonstrate that a lower concentration of metallodendrimer is needed to achieve $50 \%$ inhibition of cancer cell growth compared to Rucp and cisPt.

Several studies have shown that the direct administration of chemotherapeutic drugs for lung cancer significantly improves the exposure and residence of the drug in comparison with intravenous administration treatments. PEGylated polylysine dendrimers, conjugated to doxorubicin (DOX) to promote the controlled and prolonged exposure of lung-resident cancer to the cytotoxic drug, have been studied. The results show that PEGylated polylysine dendrimers have great potential as inhalable chemotherapeutic nanoformulations, improving the exposure of lung tumor to a cytotoxic drug [106]. Likewise, conjugates of DOX linked to PEGylated G4-polylysine dendrimer were studied to determine drug delivery kinetics, intravenous, and pulmonary pharmacokinetics in rats [107]. Cathepsin B-cleavable peptides were used to drug-linker since the extracellular and lysosomal expression of this enzyme is highly upregulated by cancer cells.

Cis-diamminodichloridoplatinum (II) (CDDP) is a anticancer drug used for the treatment of lung cancer. This drug intercalates into the cellular DNA, forming DNA adducts resulting in apoptosis [108]. A novel strategy chemotherapeutic combination for lung cancer was developed based on a folic acid (FA) conjugated polyamidoamine dendrimer. This formulation was proposed for co-delivery of siRNA against human antigen $\mathrm{R}$ and cis-diamine platinum (CDDP) to folate receptor- $\alpha$ (FRA) overexpressing (H1299) lung cancer cell [109] (Scheme 8). Studies reveal that folic acid-conjugated dendrimers generate considerable DNA damage and apoptosis cell death compared to non-functionalized nanoparticles with FA. 


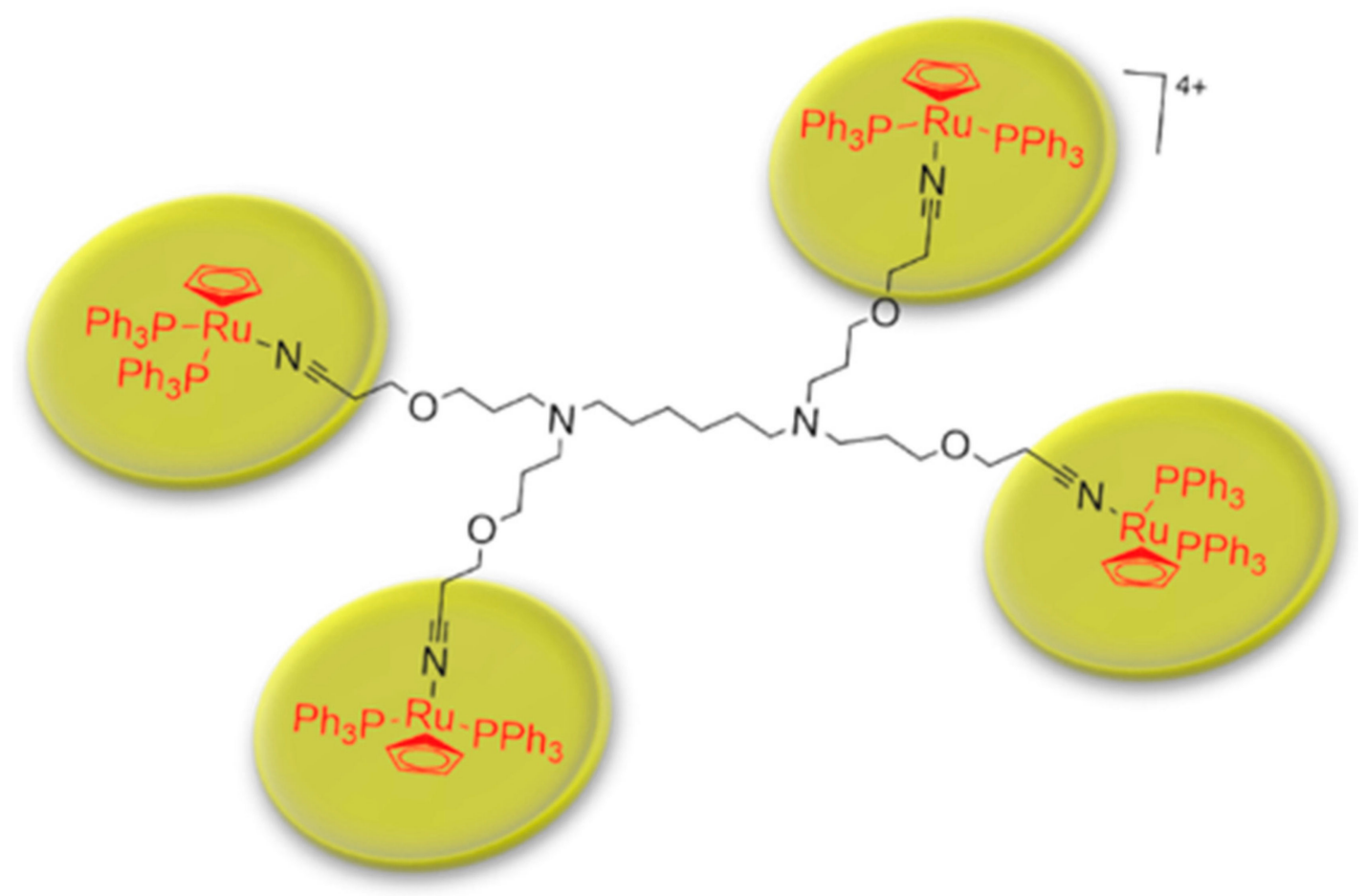

Scheme 7. Schematic representation of metallodendrimer base on poly(alkylidenimine) dendrimer core containing nitrile groups and functionalized with $\left[\mathrm{Ru}\left(\eta^{5}-\mathrm{C}_{5} \mathrm{H}_{5}\right)\left(\mathrm{PPh}_{3}\right)_{2} \mathrm{Cl}\right]$ compound. This scheme was provided thanks to Reference [105].

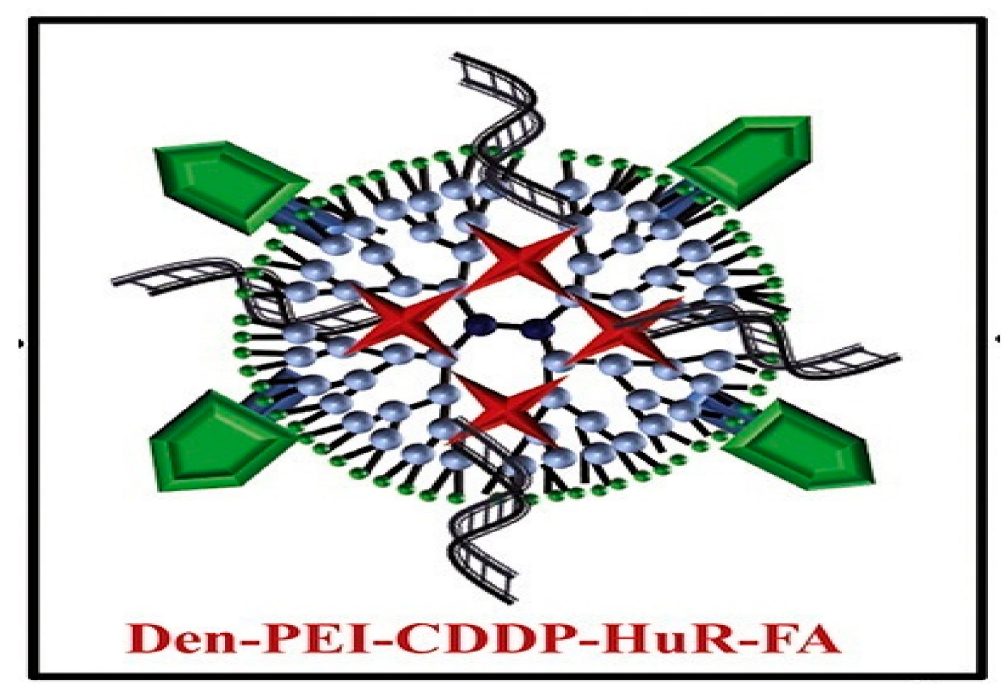

Scheme 8. Therapeutic nanoformulation based on polyethyleneimine dendrimer functionalized with folic acid (FA), human antigen $\mathrm{R}(\mathrm{HuR})$, and cis-diamine platinum (CDDP). This scheme was provided thanks to Reference [109].

While positively charged dendrimers possess considerable cellular cytotoxicity, other strategies have been proposed to formulate dendritic nanoparticles. The formulation of dendrimers negatively charged on the surface has been proposed as a way to increase the viability of healthy tissues. Negatively charged poly(amido amine)-2,3-dimethylmaleic monoamine (PAMAM-DMA) dendrimers were prepared by Cao et al. [110], which possess the capacity to change their load in response to acid $\mathrm{pH}$, present in a tumor environment. Low cytotoxicity in the normal/neutral environment was observed for negatively charged PAMAM-DMA dendrimers. Co-administration of DOX plus G5-PAMAM-DMA 
in mice bearing MCF-7 tumors enhanced the efficacy of tumor growth inhibition compared with the administration of free DOX.

Li et al. [111] has developed a novel and practical photothermal hydrogel, based on platinum nanoparticles encapsulated with dendrimer (DEPts) dextran. Photothermal hydrogel allowed repeating the photothermal therapy (PTT) and reduced the toxicity induced by long-term retention. The hydrogel represented an excellent photothermal effect and excellent biocompatibility. It was able to remain in tumors for days to allow repeated PTT, leading to complete tumor regression. Additionally, anti-Flt1 antibody-conjugated polyethylene glycol (PEG)-cored poly(amidoamine) (PAMAM) dendrimers improve the effectiveness of the gemcitabine against pancreatic cancer. Tissues, such as the liver and the bone marrow, which are known to have high vascular endothelial growth factor (VEGF)-Flt1 pathway activity, were targeted by gemcitabine when delivered through anti-Flt1 antibody-conjugated PAMAM dendrimers [112]. The advantage of using chemotherapeutic agents complexed with dendrimers not only improve anticancer efficacy but also assist in the elimination of the tumor-induced myeloid cells.

Undoubtedly it can be said that transport systems for cancer drugs based on dendrimers are the most studied and published [113-118]. This high interest is due to its versatility to mold them to the need of the system under study. A large number of works every year are published on these drug nanocarriers.

\subsection{Dendrimer as Drug Delivery Systems to Cardiovascular Treatments}

Cardiovascular diseases (CVDs) remains the leading cause of morbidity and mortality around the world. CVDs include diseases to heart, vascular diseases of brain and diseases of blood vessels, and are responsible for over 17.3 million deaths per year [119]. This pathology is associated with the upregulation of inflammatory genes. Gene silencing using RNA interference is a technic to regulate gene expression in CVDs, but the lack of efficient delivery systems has prevented its correct application. An important hormonal system involved in CVDs is the Renin-Angiotensin-Aldosterone System (RAAS). Angiotensin II (Ang II), a peptide of eight amino acids regulates the main effects of RAAS [120]. Therefore, overexpression of Ang II can cause a series of complications that can lead to heart failure. Due to these reasons, the inhibition of Ang II activation is an objective within the therapies for CVDs [121]. Liu et al. formulated a nanocarrier to complex siRNA and a cell penetration peptide (CPP) that allows improving the internalization of complexed siRNA within cardiomyocytes [122]. PEG segment was included in the structure to reduce the PAMAM toxicity. The results display that CPP conjugated with dendrimer was non-toxic and efficient to the siRNA delivery system. Bioinformatic analysis showed that the molar ratio of union between Ang-(1-7) and PAMAM-OH dendrimer as 2:1. Molecular dynamics simulation analysis revealed that the ability of neutral PAMAM-OH to protect Ang-(1-7) and form stable complexes. In short, the complex Ang-(1-7)/PAMAM-OH is an efficient administration method for Ang-(1-7), since it improves the anti-atrophic activity of this peptide in skeletal [123].

Myocardial ischemia can be addressed through gene therapy of vascular endothelial growth factor (VEGF) to promote therapeutic angiogenesis. However, the unregulated expression of VEGF and the use of viral vectors have stopped angiogenic therapy. Won et al. developed and evaluated a bioreducible polymer dendrimer-type, PAM-ABP to conjugate with a VEGF plasmid, pb-SP-ODD-VEGF [124]. This complex base on a dendrimer shows great potential as a therapy for the treatment of myocardial ischemia and infarction.

\section{Conclusions}

Dendrimers are multifunctional macromolecules that can be used in several fields. The nano-size, tunable surface, interaction with cell membranes, interaction with drugs, interior cavities, among other features, make dendrimers excellent candidates for drug delivery systems (DDS). Due to their chemical versatility, dendrimers have been applied to the transport of various types of bioactive molecules, namely drug-type molecules and genes. In the last decade, the use of dendrimer as 
DDS has been reported approximately one thousand publications, according to the WOS database. Mainly, the highest number of researches in the area of DDS using dendrimers has been for cancer diseases. A large number of studies reported for lung cancer involving dendrimers have been reported. In past years, the DDS for lung cancer has combined strategies, conjugating drugs in dendrimers, as well as gene agents for cell recognition. In addition, dendrimers are being studied as DDS in cardiovascular diseases. Due to low bioavailability and low cellular transfection of some bioactive molecules, formulations have been prepared to inhibit agents that affect cardiovascular pathologies, e.g., angiotensin has been conjugated with dendrimers to form stable complexes [125]. The controlled release of therapeutic agents and decreasing of side effects are challenges that are continuously being addressed by researchers. In conclusion, dendrimers are amazing macromolecular platforms that can be modified depending on the chemical nature of the drug that will be transported and also the target tissue. The physicochemical properties of dendrimers are important to study to understand the transport and release of drugs, as well as internalization and intracellular traffic.

Funding: This research received no external funding.

Acknowledgments: The author Sandoval-Yañez thanks to Engineering Faculty of Universidad Autonoma de Chile and C. Castro thanks to Universidad de Tarapacá.

Conflicts of Interest: The authors declare no conflict of interest.

\section{References}

1. Servati, N.; Priano, J.; Vilar, J.; Schiel, J. A cool side effect of valproic acid administration: Single dose-induced hypothermia. Am. J. Emerg. Med. 2018, 36, 2129.e3-2129.e4. [CrossRef] [PubMed]

2. Mello-Andrade, F.; Cardoso, C.G.; E Silva, C.R.; Chen-Chen, L.; De Melo-Reis, P.R.; De Lima, A.P.; Oliveira, R.; Ferraz, I.B.M.; Grisolia, C.K.; Almeida, M.A.P.; et al. Acute toxic effects of ruthenium (II)/amino acid/diphosphine complexes on Swiss mice and zebrafish embryos. Biomed. Pharmacother. 2018, 107, 1082-1092. [CrossRef] [PubMed]

3. Tian, F.; Lin, X.; Valle, R.P.; Zuo, Y.Y.; Gu, N. Poly(amidoamine) Dendrimer as a Respiratory Nanocarrier: Insights from Experiments and Molecular Dynamics Simulations. Langmuir 2019, 35, 5364-5371. [CrossRef] [PubMed]

4. Lei, J.; Rosenzweig, J.M.; Mishra, M.K.; AlShehri, W.; Brancusi, F.; McLane, M.; Almalki, A.; Bahabry, R.; Arif, H.; Rozzah, R.; et al. Maternal dendrimer-based therapy for inflammation-induced preterm birth and perinatal brain injury. Sci. Rep. 2017, 7, 6106. [CrossRef] [PubMed]

5. Khan, A.R.; Liu, M.; Khan, M.W.; Zhai, G. Progress in brain targeting drug delivery system by nasal route. J. Control. Release 2017, 268, 364-389. [CrossRef]

6. Zhang, M.; Xu, C.; Wen, L.; Han, M.K.; Xiao, B.; Zhou, J.; Zhang, Y.; Zhang, Z.; Viennois, E.; Merlin, D. A Hyaluronidase-Responsive Nanoparticle-Based Drug Delivery System for Targeting Colon Cancer Cells. Cancer Res. 2016, 76, 7208-7218. [CrossRef]

7. Hao, Y.; Li, W.; Zhou, X.; Yang, F.; Qian, Z. Microneedles-Based Transdermal Drug Delivery Systems: A Review. J. Biomed. Nanotechnol. 2017, 13, 1581-1597. [CrossRef]

8. Printz, C. Researchers develop drug delivery system to slow and control tumors. Cancer 2016, 122, 3751. [CrossRef]

9. Turato, C.; Balasso, A.; Carloni, V.; Tiribelli, C.; Mastrotto, F.; Mazzocca, A.; Pontisso, P. New molecular targets for functionalized nanosized drug delivery systems in personalized therapy for hepatocellular carcinoma. J. Control. Release 2017, 268, 184-197. [CrossRef]

10. Wang, F.; Porter, M.; Konstantopoulos, A.; Zhang, P.; Cui, H. Preclinical development of drug delivery systems for paclitaxel-based cancer chemotherapy. J. Control. Release 2017, 267, 100-118. [CrossRef]

11. Selvakumaran, S.; Muhamad, I.I. Evaluation of kappa carrageenan as potential carrier for floating drug delivery system: Effect of cross linker. Int. J. Pharm. 2015, 496, 323-331. [CrossRef] [PubMed]

12. Saini, K.; Prabhuraj, R.S.; Bandyopadhyaya, R. Development of Mesoporous Silica Nanoparticles of Tunable Pore Diameter for Superior Gemcitabine Drug Delivery in Pancreatic Cancer Cells. J. Nanosci. Nanotechnol. 2020, 20, 3084-3096. [CrossRef] [PubMed] 
13. Miguel Espinoza, S.; Patil, H.I.; San Martin Martinez, E.; Casanas Pimentel, R.; Ige, P.P. Poly-epsilon-caprolactone (PCL), a promising polymer for pharmaceutical and biomedical applications: Focus on nanomedicine in cancer. Int. J. Polym. Mater. Polym. Biomater. 2020, 69, 85-126. [CrossRef]

14. Halder, S.; Ogino, M.; Seto, Y.; Sato, H.; Onoue, S. Improved biopharmaceutical properties of carvedilol employing $\alpha$-tocopheryl polyethylene glycol 1000 succinate-based self-emulsifying drug delivery system. Drug Dev. Ind. Pharm. 2018, 44, 1838-1844. [CrossRef] [PubMed]

15. Sala, M.; Diab, R.; Elaïssari, A.; Fessi, H. Lipid nanocarriers as skin drug delivery systems: Properties, mechanisms of skin interactions and medical applications. Int. J. Pharm. 2018, 535, 1-17. [CrossRef] [PubMed]

16. Patty, P.J.; Wattimena, S.C. lipid vesicles: physical properties and application as nanocarriers in drug delivery systems. Int. J. Health Med. Curr. Res. 2017, 2, 716-722. [CrossRef]

17. Vergara-Jaque, A.; Comer, J.; Monsalve, L.; González-Nilo, F.D.; Sandoval, C. Computationally Efficient Methodology for Atomic-Level Characterization of Dendrimer-Drug Complexes: A Comparison of Amineand Acetyl-Terminated PAMAM. J. Phys. Chem. B 2013, 117, 6801-6813. [CrossRef]

18. Tomalia, D.A.; Fréchet, J.M.J. Discovery of dendrimers and dendritic polymers: A brief historical perspective. J. Polym. Sci. Part A Polym. Chem. 2002, 40, 2719-2728. [CrossRef]

19. Lee, C.C.; A Mackay, J.; Fréchet, J.M.J.; Szoka, F.C. Designing dendrimers for biological applications. Nat. Biotechnol. 2005, 23, 1517-1526. [CrossRef]

20. Majoral, J.-P.; Caminade, A.-M. Dendrimers containing heteroatoms (si, p, B, ge, or bi). Chem. Rev. 1999, 99, 845-880. [CrossRef]

21. Mekelburger, H.-B.; Vögtle, F.; Jaworek, W. Dendrimers, Arborols, and Cascade Molecules: Breakthrough into Generations of New Materials. Angew. Chem. Int. Ed. 1992, 31, 1571-1576. [CrossRef]

22. Newkome, G.R.; Keith, J.M.; Baker, G.R.; Escamilla, G.H.; Moorefield, C.N. Chemistry within a Unimolecular Micelle Precursor: Boron Superclusters by Site- and Depth-Specific Transformations of Dendrimers. Angew. Chem. Int. Ed. 1994, 33, 666-668. [CrossRef]

23. Newkome, G.R.; Yao, Z.; Baker, G.R.; Gupta, V.K. Micelles. Part 1. Cascade molecules: a new approach to micelles. A [27]-arborol. J. Org. Chem. Am. Chem. Soc. 2002, 50, 2003-2004. [CrossRef]

24. Hawker, C.J.; Fréchet, J.M. Unusual macromolecular architectures: The convergent growth approach to dendritic polyester and novel block copolymers. J. Am. Chem. Soc. 1992, 114, 8405-8413. [CrossRef]

25. Anandhan, R.; Reddy, M.B.; Sasikumar, M. Development of novel triazole based dendrimer supported spiroborate chiral catalysts for the reduction of (E)-O-benzyl oxime: An enantioselective synthesis of (S)-dapoxetine. New J. Chem. 2019, 43, 15052-15056. [CrossRef]

26. Walter, M.V.; Malkoch, M. Simplifying the synthesis of dendrimers: accelerated approaches. Chem. Soc. Rev. 2012, 41, 4593. [CrossRef]

27. Nanjwade, B.K.; Bechra, H.M.; Derkar, G.K.; Manvi, F.; Nanjwade, V.K. Dendrimers: Emerging polymers for drug-delivery systems. Eur. J. Pharm. Sci. 2009, 38, 185-196. [CrossRef]

28. Grande, J.B.; Urlich, T.; Dickie, T.; Brook, M.A. Silicone dendrons and dendrimers from orthogonal SiH coupling reactions. Polym. Chem. 2014, 5, 6728-6739. [CrossRef]

29. Maraval, V.; Pyzowski, J.; Caminade, A.-M.; Majoral, J.-P. “Lego" Chemistry for the Straightforward Synthesis of Dendrimers. J. Org. Chem. 2003, 68, 6043-6046. [CrossRef]

30. Deraedt, C.; D’Halluin, M.; Lesturgez, S.; Salmon, L.; Goglio, G.; Ruiz, J.; Astruc, D. Alkynyl-Functionalized Imidazolium for "Click" Dendrimer Functionalisation and Palladium Nanoparticle Stabilization. Eur. J. Inorg. Chem. 2015, 2015, 1345-1350. [CrossRef]

31. Lowe, A.B. Thiol-yne 'click'/coupling chemistry and recent applications in polymer and materials synthesis and modification. Polymer 2014, 55, 5517-5549. [CrossRef]

32. Amir, R.J.; Albertazzi, L.; Willis, J.; Khan, A.; Kang, T.; Hawker, C.J. Multifunctional trackable dendritic scaffolds and delivery agents. Angew. Chem. Int. Ed. 2011, 50, 3425-3429. [CrossRef] [PubMed]

33. Lowe, A.B. Thiol-ene "click" reactions and recent applications in polymer and materials synthesis: A first update. Polym. Chem. 2014, 5, 4820-4870. [CrossRef]

34. Anandkumar, D.; Rajakumar, P. Synthesis and anticancer activity of bile acid dendrimers with triazole as bridging unit through click chemistry. Steroids 2017, 125, 37-46. [CrossRef]

35. Sherje, A.P.; Jadhav, M.; Dravyakar, B.R.; Kadam, D. Dendrimers: A versatile nanocarrier for drug delivery and targeting. Int. J. Pharm. 2018, 548, 707-720. [CrossRef] 
36. Juárez-Chávez, L.; Pina-Canseco, S.; Soto-Castro, D.; Santillan, R.; Magaña-Vergara, N.E.; Salazar-Schettino, P.M.; Cabrera-Bravo, M.; Pérez-Campos, E. In vitro activity of steroidal dendrimers on Trypanosoma cruzi epimastigote form with PAMAM dendrons modified by "click" chemistry. Bioorganic Chem. 2019, 86, 452-458. [CrossRef]

37. Liu, M.; Hou, Z.; Gou, L.; Zhang, P.; Huang, B. The preparation, characterization, and properties of silver nanoparticle reinforced reduced graphene oxide-poly(amidoamine) nanocomposites. J. Appl. Polym. Sci. 2017, 134, 45172. [CrossRef]

38. Julia, B.; Vladimir, R.; Vadim, K.V.; Volodymyr, F.; Oleg, L. An optimized divergent synthesis of sulfonimidebased dendrimers achieving the fifth generation. Synthetic Communications. Taylor Fr. 2020, 49, 3536-3545. [CrossRef]

39. Urzúa, J.I.; Torneiro, M. Divergent Synthesis of Porous Tetraphenylmethane Dendrimers. J. Org. Chem. 2017, 82, 13231-13238. [CrossRef]

40. Alsehli, M.; Al-Raqa, S.Y.; Kucukkaya, I.; Shipley, P.R.; Wagner, B.D.; Abd-El-Aziz, A.S. Synthesis and Photophysical Properties of a Series of Novel Porphyrin Dendrimers Containing Organoiron Complexes. J. Inorg. Organomet. Polym. Mater. 2019, 29, 628-641. [CrossRef]

41. Gholipour-Mahmoudalilou, M.; Roghani-Mamaqani, H.; Azimi, R.; Abdollahi, A. Preparation of hyperbranched poly (amidoamine)-grafted graphene nanolayers as a composite and curing agent for epoxy resin. Appl. Surf. Sci. 2018, 428, 1061-1069. [CrossRef]

42. Kathiresan, M.; Steinhoff, H.; Walder, L. TEMPO-Labeled Viologen Dendrimers: Synthesis, Characterization, and Preliminary Distance Measurements. Macromol. Chem. Phys. 2017, 218, 1700142. [CrossRef]

43. Kaufman, E.A.; Tarallo, R.; Elacqua, E.; Carberry, T.P.; Weck, M. Synthesis of Well-Defined Bifunctional Newkome-Type Dendrimers. Macromolecules 2017, 50, 4897-4905. [CrossRef]

44. Dadapeer, E.; Prasad, G.S.; Raju, C.N. Synthesis, spectral characterization, electron microscopic study and thermogravimetric analysis of phosphorus containing dendrimer with 4-chlorophenylboronic acid at the core. Indian J. Chem. Sect. B Org. Chem. Incl. Med. Chem. 2017, 56, 127-133.

45. Patil, N.G.; Augustine, R.; Zhang, Y.; Hong, S.C.; Kim, I. Synthesis of Stimuli-Responsive Heterofunctional Dendrimer by Passerini Multicomponent Reaction. ACS Omega 2019, 4, 6660-6668. [CrossRef]

46. Merhi, A.; Grelaud, G.; Morshedi, M.; Abid, S.; Green, K.A.; Barlow, A.; Groizard, T.; Kahlal, S.; Halet, J.-F.; Ngo, H.M.; et al. Synthesis, characterization and third-order nonlinear optical properties of a dodecaruthenium organometallic dendrimer with a zinc(ii) tetraphenylporphyrin core. Dalton Trans. 2018, 47, 11123-11135. [CrossRef]

47. Selvarani, S.; Rajakumar, P. Synthesis, Photochemical, Electrochemical and Cytotoxic Studies on Azobenzene Cored Dendrimer Decorated with Chalcone Motif. ChemistrySelect 2018, 3, 5455-5460. [CrossRef]

48. Dayyani, N.; Ramazani, A.; Khoee, S.; Shafiee, A. Synthesis and Characterization of the First Generation of Polyamino-Ester Dendrimer-Grafted Magnetite Nanoparticles from 3-Aminopropyltriethoxysilane (APTES) via the Convergent Approach. Silicon 2018, 10, 595-601. [CrossRef]

49. Guizzardi, R.; Vacchini, M.; Santambrogio, C.; Cipolla, L. Convergent dendrimer synthesis by olefin metathesis and studies toward glycoconjugation. Can. J. Chem. 2017, 95, 1008-1012. [CrossRef]

50. Singh, P. Synthesis of mesitylene-based polyamine dendrimer for functionalisation of single-walled carbon nanotubes. J. Exp. Nanosci. 2015, 10, 429-437. [CrossRef]

51. Khoee, S.; Hemati, K. Synthesis of magnetite/polyamino-ester dendrimer based on PCL/PEG amphiphilic copolymers via convergent approach for targeted diagnosis and therapy. Polymer 2013, 54, 5574-5585. [CrossRef]

52. Pu-Guang, C.; Zhi-Hua, H.; Zhan-Yi, S.; Qian-Qian, L.; Yong-Xiang, C.; Yu-Fen, Z.; Yan-Mei, L. Synthesis of an MUC1 Glycopeptide Dendrimer Based on $\beta$-Cyclodextrin by Click Chemistry. Synlett 2017, 28, 1961-1965. [CrossRef]

53. Fan, X.; Hu, Z.; Wang, G. Facile synthesis of polyester dendrimer via combining thio-bromo "Click" chemistry and ATNRC. J. Polym. Sci. Part A Polym. Chem. 2015, 53, 1762-1768. [CrossRef]

54. Han, S.C.; Choi, I.-H.; Jin, S.-H.; Lee, J.W. Efficient Synthesis of Carbazole Core Diblock Dendrimer by Double Click Chemistry. Mol. Cryst. Liq. Cryst. 2014, 599, 86-95. [CrossRef]

55. Casey, B.K.; Grayson, S.M. The Potential of Amine-Containing Dendrimer Mass Standards for Internal Calibration of Peptides. Eur. J. Mass Spectrom. 2015, 21, 747-752. [CrossRef] 
56. Bhattacharya, P.; Nasybulin, E.N.; Engelhard, M.H.; Kovarik, L.; Bowden, M.E.; Li, X.S.; Gaspar, D.J.; Xu, W.; Zhang, J.-G. Dendrimer-Encapsulated Ruthenium Oxide Nanoparticles as Catalysts in Lithium-Oxygen Batteries. Adv. Funct. Mater. 2014, 24, 7510-7519. [CrossRef]

57. Hlídková, H.; Kotelnikov, I.; Pop-Georgievski, O.; Proks, V.; Horák, D. Antifouling Peptide Dendrimer Surface of Monodisperse Magnetic Poly(glycidyl methacrylate) Microspheres. Macromolecules 2017, 50, 1302-1311. [CrossRef]

58. Stenström, P.; Hjorth, E.; Zhang, Y.; Andrén, O.C.J.; Guette-Marquet, S.; Schultzberg, M.; Malkoch, M. Synthesis and in Vitro Evaluation of Monodisperse Amino-Functional Polyester Dendrimers with Rapid Degradability and Antibacterial Properties. Biomacromolecules 2017, 18, 4323-4330. [CrossRef]

59. Malý, J.; Staněk, O.; Frolík, J.; Ennen, F.; Appelhans, D.; Semerádtová, A.; Wrobel, D.; Štofik, M.; Knapova, T.; Kuchař, M.; et al. Biocompatible Size-Defined Dendrimer-Albumin Binding Protein Hybrid Materials as a Versatile Platform for Biomedical Applications. Macromol. Biosci. 2016, 16, 553-566. [CrossRef]

60. Wang, B.; Sun, Y.; Davis, T.P.; Ke, P.C.; Wu, Y.; Ding, F. Understanding Effects of PAMAM Dendrimer Size and Surface Chemistry on Serum Protein Binding with Discrete Molecular Dynamics Simulations. ACS Sustain. Chem. Eng. 2018, 6, 11704-11715. [CrossRef]

61. Erturk, A.S.; Gurbuz, M.U.; Tulu, M. The effect of PAMAM dendrimer concentration, generation size and surface functional group on the aqueous solubility of candesartan cilexetil. Pharm. Dev. Technol. 2017, 22, 111-121. [CrossRef] [PubMed]

62. Kim, J.-H.; Yoon, H.-J.; Sim, J.; Ju, S.-Y.; Jang, W.-D. The effects of dendrimer size and central metal ions on photosensitizing properties of dendrimer porphyrins. J. Drug Target. 2014, 22, 610-618. [CrossRef] [PubMed]

63. Cheng, Y.; Xu, Z.; Ma, M.; Xu, T. Dendrimers as Drug Carriers: Applications in Different Routes of Drug Administration. J. Pharm. Sci. 2008, 97, 123-143. [CrossRef] [PubMed]

64. Gupta, S.; Biswas, P. Effect of $\mathrm{pH}$ on Size and Internal Structure of Poly(propylene imine) Dendrimers: A Molecular Dynamics Simulation Study. J. Phys. Chem. B 2018, 122, 9250-9263. [CrossRef] [PubMed]

65. Kavyani, S.; Amjad-Iranagh, S.; Dadvar, M.; Modarress, H. Hybrid Dendrimers of PPI(core)-PAMAM(shell): A Molecular Dynamics Simulation Study. J. Phys. Chem. B 2016, 120, 9564-9575. [CrossRef]

66. Katzur, V.; Eichler, M.; Deigele, E.; Stage, C.; Karageorgiev, P.; Geis-Gerstorfer, J.; Schmalz, G.; Ruhl, S.; Rupp, F.; Müller, R. Surface-immobilized PAMAM-dendrimers modified with cationic or anionic terminal functions: Physicochemical surface properties and conformational changes after application of liquid interface stress. J. Colloid Interface Sci. 2012, 366, 179-190. [CrossRef]

67. Diaz, C.; Benitez, C.; Vidal, F.; Barraza, L.F.; Jiménez, V.A.; Guzman, L.; Fuentealba, J.; Yevenes, G.E.; Alderete, J.B. Cytotoxicity and in vivo plasma kinetic behavior of surface-functionalized PAMAM dendrimers. Nanomed. Nanotechnol. Boil. Med. 2018, 14, 2227-2234. [CrossRef]

68. Sadeghi-Kiakhani, M.; Safapour, S. Functionalization of poly(amidoamine) dendrimer-based nano-architectures using a naphthalimide derivative and their fluorescent, dyeing and antimicrobial properties on wool fibers. Luminescence 2016, 31, 1005-1012. [CrossRef]

69. Feng, X.; Pinaud, J.; Chaikof, E.L.; Taton, D.; Gnanou, Y. Sequential functionalization of janus-type dendrimer-like poly (ethylene oxide)s with camptothecin and folic acid. J. Polym. Sci. Part A Polym. Chem. 2011, 49, 2839-2849. [CrossRef]

70. Alfei, S.; Catena, S. Synthesis and characterization of versatile amphiphilic dendrimers peripherally decorated with positively charged amino acids. Polym. Int. 2018, 67, 1572-1584. [CrossRef]

71. Maji, R.; Omolo, C.A.; Agrawal, N.; Maduray, K.; Hassan, D.; Mokhtar, C.; Mackhraj, I.; Govender, T.; Mackraj, I. pH-Responsive Lipid-Dendrimer Hybrid Nanoparticles: An Approach To Target and Eliminate Intracellular Pathogens. Mol. Pharm. 2019, 16, 4594-4609. [CrossRef] [PubMed]

72. Jayakumar, K.; Camarada, M.B.; Rajesh, R.; Venkatesan, R.; Ju, H.; Dharuman, V.; Wen, Y.; Dharuman, V. Layer-by-layer assembled gold nanoparticles/lower-generation $(\mathrm{Gn} \leq 3)$ polyamidoamine dendrimers-grafted reduced graphene oxide nanohybrids with 3D fractal architecture for fast, ultra-trace, and label-free electrochemical gene nanobiosensors. Biosens. Bioelectron. 2018, 120, 55-63. [CrossRef] [PubMed]

73. Fox, L.J.; Richardson, R.M.; Briscoe, W.H. PAMAM dendrimer - cell membrane interactions. Adv. Colloid Interface Sci. 2018, 257, 1-18. [CrossRef] [PubMed]

74. Evans, D.; Yalkowsky, S.; Wu, S.; Pereira, D.; Fernandes, P. Overcoming the Challenges of Low Drug Solubility in the Intravenous Formulation of Solithromycin. J. Pharm. Sci. 2018, 107, 412-418. [CrossRef] [PubMed] 
75. Kalantar, T.; Zhao, J.; Ladika, M.; Harris, K.; Tucker, C.; Tulchinsky, M.; Keifer, J.; Chen, S.; Krystosek, R.; Guillaudeu, S.J.; et al. Use of high throughput methods in the discovery of novel excipient-solubilizers for drugs with low aqueous solubility. Abstr. Pap. Am. Chem. Soc. 2018, 255.

76. Choudhary, S.; Gupta, L.; Rani, S.; Dave, K.; Gupta, U. Impact of Dendrimers on Solubility of Hydrophobic Drug Molecules. Front. Pharmacol. 2017, 8, 17-23. [CrossRef]

77. Benet, L.Z.; Broccatelli, F.; Oprea, T.I. BDDCS Applied to Over 900 Drugs. AAPS J. 2011, 13, $519-547$. [CrossRef]

78. Mueller, C.E. Prodrug Approaches for Enhancing the Bioavailability of Drugs with Low Solubility. Chem. Biodivers. 2009, 6, 2071-2083. [CrossRef]

79. Alfei, S.; Taptue, G.B.; Catena, S.; Bisio, A. Synthesis of Water-soluble, Polyester-based Dendrimer Prodrugs for Exploiting Therapeutic Properties of Two Triterpenoid Acids. Chin. J. Polym. Sci. 2018, 36, 999-1010. [CrossRef]

80. Nicolson, G.L. The Fluid-Mosaic Model of Membrane Structure: Still relevant to understanding the structure, function and dynamics of biological membranes after more than 40 years. Biochim. et Biophys. Acta BBA Biomembr. 2014, 1838, 1451-1466. [CrossRef]

81. Lombardo, D.; Calandra, P.; Magazù, S.; Wanderlingh, U.; Barreca, D.; Pasqua, L.; Kiselev, M.A. Soft nanoparticles charge expression within lipid membranes: The case of amino terminated dendrimers in bilayers vesicles. Colloids Surfaces B Biointerfaces 2018, 170, 609-616. [CrossRef] [PubMed]

82. Bertrand, N.; Wu, J.; Xu, X.; Kamaly, N.; Farokhzad, O.C. Cancer nanotechnology: The impact of passive and active targeting in the era of modern cancer biology. Adv. Drug Deliv. Rev. 2014, 66, 2-25. [CrossRef] [PubMed]

83. Liu, J.-P.; Wang, T.-T.; Wang, D.-G.; Dong, A.-J.; Li, Y.-P.; Yu, H.-J. Smart nanoparticles improve therapy for drug-resistant tumors by overcoming pathophysiological barriers. Acta Pharmacol. Sin. 2016, 38, 1-8. [CrossRef] [PubMed]

84. Saw, P.E.; Park, J.; Jon, S.; Farokhzad, O.C. A drug-delivery strategy for overcoming drug resistance in breast cancer through targeting of oncofetal fibronectin. Nanomed. Nanotechnol. Boil. Med. 2017, 13, 713-722. [CrossRef]

85. Zhang, X.; Li, Y.; Hu, C.; Wu, Y.; Zhong, D.; Xu, X.; Gu, Z. Engineering Anticancer Amphipathic Peptide-Dendronized Compounds for Highly-Efficient Plasma/Organelle Membrane Perturbation and Multidrug Resistance Reversal. ACS Appl. Mater. Interfaces 2018, 10, 30952-30962. [CrossRef]

86. Vidal, F.; Vásquez, P.; Cayumán, F.; Diaz, C.; Fuentealba, J.; Aguayo, L.; Yévenes, G.E.; Alderete, J.; Guzmán, L. Prevention of Synaptic Alterations and Neurotoxic Effects of PAMAM Dendrimers by Surface Functionalization. Nanomaterials. Multidiscip. Digit. Publ. Inst. 2018, 8, 7. [CrossRef]

87. LaVan, M.; Knipp, G. Effects of Dendrimer-Like Biopolymers on Physical Stability of Amorphous Solid Dispersions and Drug Permeability Across Caco-2 Cell Monolayers. AAPS PharmSciTech 2018, 19, 2459-2471. [CrossRef]

88. Falanga, A.; Lombardi, L.; Tarallo, R.; Franci, G.; Perillo, E.; Palomba, L.; Galdiero, M.; Pontoni, D.; Fragneto, G.; Weck, M.; et al. The intriguing journey of gH625-dendrimers. RSC Adv. 2017, 7, 9106-9114. [CrossRef]

89. Chan, C.-O.; Jing, J.; Xiao, W.; Tan, Z.; Lv, Q.; Yang, J.; Chen, S. Enhanced Intestinal Permeability of Bufalin by a Novel Bufalin-Peptide-Dendrimer Inclusion through Caco-2 Cell Monolayer. Molecules 2017, $22,2088$. [CrossRef]

90. Qi, X.; Qin, J.; Fan, Y.; Qin, X.; Jiang, Y.; Wu, Z.; Xiaole, Q.; Jiayi, Q.; Yuchao, F.; Xiaoxue, Q.; et al. Carboxymethyl Chitosan-Modified Polyamidoamine Dendrimer Enables Progressive Drug Targeting of Tumors via pH-Sensitive Charge Inversion. J. Biomed. Nanotechnol. 2016, 12, 667-678. [CrossRef]

91. Otto, D.P.; De Villiers, M.M. All-atomistic molecular dynamics (AA-MD) studies and pharmacokinetic performance of PAMAM-dendrimer-furosemide delivery systems. Int. J. Pharm. 2018, 547, 545-555. [CrossRef] [PubMed]

92. Mehrizi, T.Z.; Ardestani, M.S.; Khamesipour, A.; Hoseini, M.H.M.; Mosaffa, N.; Anissian, A.; Ramezani, A. Reduction toxicity of Amphotericin B through loading into a novel nanoformulation of anionic linear globular dendrimer for improve treatment of leishmania major. J. Mater. Sci. Mater. Electron. 2018, 29, 125. [CrossRef] [PubMed] 
93. Burman, W.J.; Gallicano, K.; Peloquin, C.; Burman, W.J. Comparative Pharmacokinetics and Pharmacodynamics of the Rifamycin Antibacterials. Clin. Pharmacokinet. 2001, 40, 327-341. [CrossRef] [PubMed]

94. Bellini, R.G.; Guimarães, A.P.; Pacheco, M.A.; Dias, D.M.; Furtado, V.R.; De Alencastro, R.B.; Horta, B.A. Association of the anti-tuberculosis drug rifampicin with a PAMAM dendrimer. J. Mol. Graph. Model. 2015, 60, 34-42. [CrossRef]

95. Nasr, M.; Najlah, M.; D'Emanuele, A.; Elhissi, A. PAMAM dendrimers as aerosol drug nanocarriers for pulmonary delivery via nebulization. Int. J. Pharm. 2014, 461, 242-250. [CrossRef]

96. Dong, Z.; Hamid, K.A.; Gao, Y.; Lin, Y.; Katsumi, H.; Sakane, T.; Yamamoto, A. Polyamidoamine Dendrimers Can Improve the Pulmonary Absorption of Insulin and Calcitonin in Rats. J. Pharm. Sci. 2011, 100, 1866-1878. [CrossRef]

97. Sharma, A.K.; Gothwal, A.; Kesharwani, P.; Alsaab, H.; Iyer, A.K.; Gupta, U. Dendrimer nanoarchitectures for cancer diagnosis and anticancer drug delivery. Drug Discov. Today 2017, 22, 314-326. [CrossRef]

98. Carrasco-Sanchez, V.; Vergara-Jaque, A.; Zuñiga, M.; Comer, J.; John, A.; Nachtigall, F.M.; Valdés, O.; Duran-Lara, E.F.; Sandoval, C.; Santos, L.S. In situ and in silico evaluation of amine- and folate-terminated dendrimers as nanocarriers of anesthetics. Eur. J. Med. Chem. 2014, 73, 250-257. [CrossRef]

99. Li, Y.; Huang, G.; Diakur, J.; Wiebe, L. Targeted Delivery of Macromolecular Drugs: Asialoglycoprotein Receptor (ASGPR) Expression by Selected Hepatoma Cell Lines used in Antiviral Drug Development. Curr. Drug Deliv. 2008, 5, 299-302. [CrossRef]

100. Liu, H.; Wang, H.; Xu, Y.; Guo, R.; Wen, S.; Huang, Y.; Liu, W.; Shen, M.; Zhao, J.; Zhang, G.; et al. Lactobionic Acid-Modified Dendrimer-Entrapped Gold Nanoparticles for Targeted Computed Tomography Imaging of Human Hepatocellular Carcinoma. ACS Appl. Mater. Interfaces 2014, 6, 6944-6953. [CrossRef]

101. Kuruvilla, S.P.; Tiruchinapally, G.; Elazzouny, M.; Elsayed, M.E.H. N-Acetylgalactosamine-Targeted Delivery of Dendrimer-Doxorubicin Conjugates Influences Doxorubicin Cytotoxicity and Metabolic Profile in Hepatic Cancer Cells. Adv. Heal. Mater. 2017, 6, 1601046.

102. Medina, S.H.; Chevliakov, M.V.; Tiruchinapally, G.; Durmaz, Y.Y.; Kuruvilla, S.P.; Elsayed, M.E. Enzyme-activated nanoconjugates for tunable release of doxorubicin in hepatic cancer cells. Biomaterials 2013, 34, 4655-4666. [CrossRef] [PubMed]

103. Medina, S.H.; Tekumalla, V.; Chevliakov, M.V.; Shewach, D.S.; Ensminger, W.D.; El-Sayed, M.E. $\mathrm{N}$-acetylgalactosamine-functionalized dendrimers as hepatic cancer cell-targeted carriers. Biomaterials 2011, 32, 4118-4129. [CrossRef] [PubMed]

104. Kuruvilla, S.P.; Tiruchinapally, G.; Kaushal, N.; Elsayed, M.E. Effect of N-acetylgalactosamine ligand valency on targeting dendrimers to hepatic cancer cells. Int. J. Pharm. 2018, 545, 27-36. [CrossRef]

105. Gouveia, M.; Figueira, J.; Jardim, M.; Castro, R.; Tomás, H.; Rissanen, K.; Rodrigues, J. Poly(alkylidenimine) Dendrimers Functionalized with the Organometallic Moiety [Ru(n5-C5H5) (PPh3)2]+ as Promising Drugs Against Cisplatin-Resistant Cancer Cells and Human Mesenchymal Stem Cells. Mol. Multidiscip. Digit. Publ. Inst. 2018, 23, 1471. [CrossRef]

106. Kaminskas, L.M.; McLeod, V.M.; Ryan, G.M.; Kelly, B.D.; Haynes, J.M.; Williamson, M.; Thienthong, N.; Owen, D.J.; Porter, C.J. Pulmonary administration of a doxorubicin-conjugated dendrimer enhances drug exposure to lung metastases and improves cancer therapy. J. Control. Release 2014, 183, 18-26. [CrossRef]

107. Leong, N.J.; Mehta, D.; McLeod, V.M.; Kelly, B.D.; Pathak, R.; Owen, D.J.; Kaminskas, L.M.; Porter, C.J. Doxorubicin Conjugation and Drug Linker Chemistry Alter the Intravenous and Pulmonary Pharmacokinetics of a PEGylated Generation 4 Polylysine Dendrimer in Rats. J. Pharm. Sci. 2018, 107, 2509-2513. [CrossRef]

108. Shi, S.; Tan, P.; Yan, B.; Gao, R.; Zhao, J.; Wang, J.; Guo, J.; Li, N.; Ma, Z. ER stress and autophagy are involved in the apoptosis induced by cisplatin in human lung cancer cells. Oncol. Rep. 2016, 35, 2606-2614. [CrossRef]

109. Amreddy, N.; Babu, A.; Panneerselvam, J.; Srivastava, A.; Muralidharan, R.; Chen, A.; Zhao, Y.D.; Munshi, A.; Ramesh, R. Chemo-biologic combinatorial drug delivery using folate receptor-targeted dendrimer nanoparticles for lung cancer treatment. Nanomed. Nanotechnol. Biol. Med. 2018, 14, 373-384. [CrossRef]

110. Cao, J.; Wang, C.; Guo, L.; Xiao, Z.; Liu, K.; Yan, H. Co-administration of a charge-conversional dendrimer enhances antitumor efficacy of conventional chemotherapy. Eur. J. Pharm. Biopharm. 2018, 127, 371-377. [CrossRef] 
111. Li, L.; Wang, C.; Huang, Q.; Xiao, J.; Zhang, Q.; Cheng, Y. A degradable hydrogel formed by dendrimer-encapsulated platinum nanoparticles and oxidized dextran for repeated photothermal cancer therapy. J. Mater. Chem. B 2018, 6, 2474-2480. [CrossRef]

112. Yoyen-Ermis, D.; Ozturk-Atar, K.; Kursunel, M.A.; Aydin, C.; Ozkazanç, D.; Gurbuz, M.U.; Uner, A.; Tulu, M.; Calis, S.; Esendagli, G.; et al. Tumor-Induced Myeloid Cells Are Reduced by Gemcitabine-Loaded PAMAM Dendrimers Decorated with Anti-Flt1 Antibody. Mol. Pharm. 2018, 15, 1526-1533. [CrossRef] [PubMed]

113. Zhong, Q. Co-Spray Dried Mannitol/Poly(amidoamine)-Doxorubicin Dry-Powder Inhaler Formulations for Lung Adenocarcinoma: Morphology, In Vitro Evaluation, and Aerodynamic Performance. AAPS PharmSciTech 2018, 19, 531-540. [CrossRef] [PubMed]

114. Lu, Y.; Han, S.; Zheng, H.; Ma, R.; Ping, Y.; Zou, J.; Tang, H.; Zhang, Y.; Xu, X.; Li, F. A novel RGDyC/PEG co-modified PAMAM dendrimer-loaded arsenic trioxide of glioma targeting delivery system. Int. J. Nanomed. 2018, 13, 5937-5952. [CrossRef] [PubMed]

115. Yamashita, S.; Katsumi, H.; Sakane, T.; Yamamoto, A. Bone-targeting dendrimer for the delivery of methotrexate and treatment of bone metastasis. J. Drug Target. 2018, 26, 818-828. [CrossRef] [PubMed]

116. Мa, J.; Yao, H. Dendrimer-paclitaxel complexes for efficient treatment in ovarian cancer: study on OVCAR-3 and HEK293T cells. Acta Biochim. Pol. 2018, 65, 219-225. [CrossRef]

117. Lin, L.; Fan, Y.; Gao, F.; Jin, L.; Li, D.; Sun, W.; Li, F.; Qin, P.; Shi, Q.; Shi, X.; et al. UTMD-Promoted Co-Delivery of Gemcitabine and miR-21 Inhibitor by Dendrimer-Entrapped Gold Nanoparticles for Pancreatic Cancer Therapy. Theranostics 2018, 8, 1923-1939. [CrossRef]

118. Sharma, A.K.; Gupta, L.; Sahu, H.; Qayum, A.; Singh, S.K.; Nakhate, K.T.; Ajazuddin; Gupta, U. Chitosan Engineered PAMAM Dendrimers as Nanoconstructs for the Enhanced Anti-Cancer Potential and Improved In vivo Brain Pharmacokinetics of Temozolomide. Pharm. Res. 2018, 35, 9. [CrossRef]

119. Mendis, S.; Puska, P.; Norrving, B. World Health Organization, Federation WH, World Stroke Organization. Global Atlas on Cardiovascular Disease Prevention and Control; World Health Organization: Geneva, Switzerland, 2011.

120. Dzau, V.J. Theodore Cooper Lecture: Tissue angiotensin and pathobiology of vascular disease: A unifying hypothesis. Hypertension 2001, 37, 1047-1052. [CrossRef]

121. Ma, T.K.; Kam, K.K.; Yan, B.P.; Lam, Y.-Y. Renin-angiotensin-aldosterone system blockade for cardiovascular diseases: current status. Br. J. Pharmacol. 2010, 160, 1273-1292. [CrossRef]

122. Liu, J.; Gu, C.; Cabigas, E.B.; Pendergrass, K.D.; Brown, M.E.; Luo, Y.; Davis, M.E. Functionalized dendrimer-based delivery of angiotensin type 1 receptor siRNA for preserving cardiac function following infarction. Biomaterials 2013, 34, 3729-3736. [CrossRef] [PubMed]

123. Márquez-Miranda, V.; Abrigo, J.; Rivera, J.C.; Araya-Durán, I.; Aravena, J.; Simon, F.; Pacheco, N.; González-Nilo, F.D.; Cabello-Verrugio, C. The complex of PAMAM-OH dendrimer with Angiotensin (1-7) prevented the disuse-induced skeletal muscle atrophy in mice. Int. J. Nanomed. 2017, 12, 1985-1999. [CrossRef] [PubMed]

124. Won, Y.-W.; McGinn, A.N.; Lee, M.; Nam, K.; Bull, D.A.; Kim, S.W. Post-translational regulation of a hypoxia-responsive VEGF plasmid for the treatment of myocardial ischemia. Biomaterials 2013, 34, 6229-6238. [CrossRef] [PubMed]

125. Akhtar, S.; El-Hashim, A.Z.; Chandrasekhar, B.; Attur, S.; Benter, I.F. Naked Polyamidoamine Polymers Intrinsically Inhibit Angiotensin II-Mediated EGFR and ErbB2 Transactivation in a Dendrimer Generationand Surface Chemistry-Dependent Manner. Mol. Pharm. 2016, 13, 1575-1586. [CrossRef] [PubMed]

(C) 2020 by the authors. Licensee MDPI, Basel, Switzerland. This article is an open access article distributed under the terms and conditions of the Creative Commons Attribution (CC BY) license (http://creativecommons.org/licenses/by/4.0/). 